\title{
Generalized Procrustes Analysis of an ontogenetic series of modified crania: Evaluating the technique of modification in the Migration Period of Europe $\left(4^{\text {th }}-7^{\text {th }}\right.$ Century AD) \\ P. Mayall ${ }^{1}$ V. Pilbrow ${ }^{1}$ \\ University of Melbourne, Parkville, Victoria, Australia, 3000.
}

Text: 21 pages

Bibliography: 9 pages

Figures: 11

Tables: 5

Abbreviated title: Ontogenetic series of modified crania

Key words: Intentional cranial modification, Georgia, Hungary, Ontogenetic allometry,

Procrustes superimposition

Varsha Pilbrow, The University of Melbourne, Parkville, Victoria, Australia, 3000

Phone: +61383445775

Fax: +61393475219

Email: vpilbrow@unimelb.edu.au

Funding information: American Association of Physical Anthropology Professional Development Grant

This is the author manuscript accepted for publication and has undergone full peer review but has not been through the copyediting, typesetting, pagination and proofreading process, which may lead to differences between this version and the Version of record. Please cite this article as doi:10.1002/ ajpa.23412. 


\section{Abstract}

\section{Objectives}

The arrival of the Huns into Europe in the fourth century AD increased the occurrence of intentional cranial modification among European nomads. It has been postulated that the Huns used a two-bandage cranial binding technique to differentiate themselves from surrounding nomadic groups, including those from Georgia. This study examines this hypothesis by comparing Migration Period $\left(4^{\text {th }}-7^{\text {th }}\right.$ Century AD) juvenile crania, which retain strong impressions of bindings, with adult modified crania from Hungary and Georgia.

\section{Materials and Methods}

Twelve surface landmarks and 251 semi-landmarks were used to study ontogenetic trajectories in nine juvenile and 16 adult modified skulls from eight Hungarian sites and 21 adult skulls from two Georgian sites. Generalized Procrustes Analysis, linear regression of Procrutes distance on dental age and log centroid size, and warping the principal components in shape space helped to identify cranial shape changes.

\section{Results}

The principal components provide significant separation of the juvenile and adult groups from Georgia and Hungary. Variation in modified cranial shape was limited in Hungary compared to Georgia. There was stronger correlation between juvenile and adult modified cranial shape in Hungary than in Georgia. Warping along the first axis reveals the trajectory from marked flattening of the frontal and occipital regions in juveniles to diminished flattening in the same 
regions in adult crania, corresponding with one binding. Another depression extending from the post-bregmatic region to the temporal region, similarly strong in juveniles but diminishing in adults, marks the second binding.

\section{Discussion}

Hungarian crania were modified with two bindings with limited shape variation, whereas the Georgian crania had greater variation in shape being also modified with antero-posterior bindings. The findings from this study alongside contemporary historical sources help to understand the role of intentional cranial modification as a mark of social identity among nomads in the Migration Period of Europe.

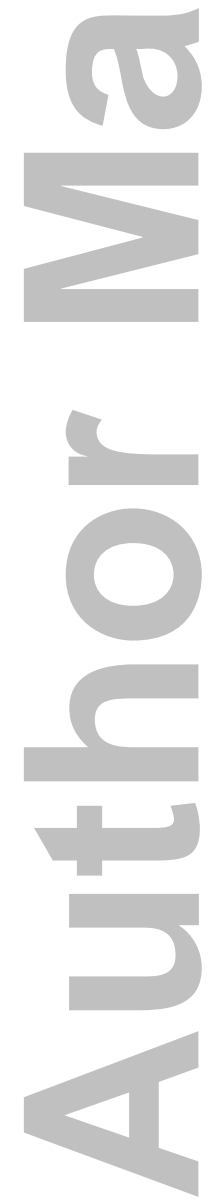




\section{Introduction}

\section{Intentional crahial modification is cultural practice where members of a social group mould the soft cranial bones of an infant into desired shape by applying tight bandages. Once the cranial bones ossify the modified head serves as a visible mark of affinity with a social group (Tiesler,} 2014). Evidence for the practice of intentional cranial modification in the Mtskheta region of the Republic of Georgia exists from the third millennium BC, but it became far more prevalent after the fourth century AD corresponding to the Migration Period (4 - 7 AD) in Europe (Dingwall, 1931; Kiszely, 1978). This is the period following the collapse of the Western Roman Empire when there was large-scale migration of Germanic and Eurasian nomadic groups around Roman territory (Halsall, 2007). The proliferation of the practice during this period is associated with the Huns, nomadic warriors from Central Asia, who settled in the Carpathian basin around Hungary and Romania in the fourth century AD (Sinor, 1990), and practiced cranial modification as a unique marker of their social identity (Werner, 1956). The Huns are largely credited with destabilizing the Western Roman Empire and setting in motion the Migration Period (Sinor, 1990; Halsall, 2007; Kim, 2013; Vaissière, 2015). They were so influential in European history that modified crania from archaeological sites in the Migration Period are attributed to the Huns (Werner, 1956; Maenchen-Helfen, 1973; Smith, 1987; Anke, 1998; Huck, 2007), even in regions where historic records do not mention the presence of Huns and despite evidence for the practice prior to the arrival of Huns in Europe. This is the case in the Mtskheta region of Georgia. From 2008 to 2011 the University of Melbourne and the Georgian National Museum carried out joint excavations at the 1500 BC to 600 AD burial site of Samtavro and found that 
roughly $24 \%$ of the excavated crania from burials dated to the Migration Period were intentionally modified. Combined with the finding of bronze mirrors, which Werner (1956) suggested are Hunnic cultural artefacts, we postulated a Hunnic link to the region (Sagona et al., 2010). To test the hypothesis that Huns were present in Georgia we subsequently used eigenshape analysis to compare adult modified crania from the Mtskheta region of Georgia with modified crania from the Carpathian basin around Hungary, where Hunnic presence was unambiguous (Mayall, Pilbrow, Bitadze, 2017). From two-dimensional analysis of the sagittal outline of the cranium, we found that the Hungarian crania were far more constrained in shape during the Migration Period, whereas modified crania from Georgia from the same time-period displayed a variety of shapes. We postulated that the technique of modification in Hungary was under strong social control and involved the use of two bindings, one circular and another vertical, whereas in Georgia, either single or double circumferential bindings resulted in a diversity of modified shapes. Based on this we suggested that other nomadic groups were involved in the practice of intentional cranial modification in Georgia, but Huns had little influence on the practice there.

Juveniles make up $36 \%$ of the sample with modified crania from Hungary and they preserve strong signs of the bindings placed in early childhood. In contrast, we do not find juveniles with modified crania in the Mtskheta region of Georgia, although juveniles make up 22\% of the skeletal sample in the region (Sagona et al., 2010). The juvenile modified crania from Hungary thus provide a unique means to test the hypothesis that people from the Hunnic region of the Carpathian Basin in the Migration Period used a specific two-binding technique, which differed from that in Georgia. 
The process of modifying the child's skull to achieve a desired shape begins at birth. The cranial vault is $25 \%$ of adult size at this time (Vinicius, 2005 ) and the bones are soft and malleable to allow passage through the birth canal. In annular or circumferential binding, caregivers wrap the bandages around the frontal, parietal and squamous portions of the temporal and occipital bones. These bones are intramembranous in ossification, with most of their growth occurring during the first and part of the second year, when sutures take up the mechanical stress from the growth of the brain, while sutural margins provide sites of bone growth through apposition (Rice, 2008). Caregivers maintain the bindings for the first few years of life while the bones are malleable and sutures unfused (Tiesler, 2014). The pressure from the bindings initiates premature closure of the sutures and changes the normal direction of cranial growth, with compensatory growth occurring perpendicular to the closure (Gerszten, 1993; Gerszten and Gerszten, 1995; Rice, 2008; Hukki, Saarinen, Kangasniemi, 2008; Tiesler, 2014). Compression in the anterior-posterior and medio-lateral directions in annular or circumferential binding forces growth in a superior direction, resulting in a tall, domed skull. We see such skulls in Georgia during the Migration Period. Modified skulls from Hungary from the same time-period show compression in the anterior-posterior and medio-lateral directions, but also in the coronal direction. Thus, they do not have a domed shape. Instead, they show bulging in the region of the parietal squama, suggesting that the adult carers placed a vertical bandage in the region of anterior fontanelle perpendicular to the circular bandages. The juvenile skulls from Hungary display clear depressions in the pathway of the bandages and provide an ideal means to study the technique of modification in the Carpathian basin in contrast with Georgia. 
In this study, we use the Evan Toolbox software (http://www.evan-society.org) to quantify cranial shape and study the pathway of the bindings in three dimensions in order to get a fuller understanding of the binding styles. We use Procrustes superimposition to compare the shape of juvenile crania from Hungary with adult crania from Hungary and Georgia. By tracing cranial shape change in an ontogenetic series and studying the correlation between the juveniles and adults in principal components defining shape we are able to gain insight into the techniques used in the modification of Hungarian and Georgian adult crania. Generalized Procrustes Analysis allows us to exclude differences in the size, orientation and position of the cranial landmark configurations, and include males, females and juveniles in the sample, leaving shape as the only remaining variable to be analysed.

\section{Materials and Methods}

\subsection{Sample}

We studied twenty-five intentionally modified crania from the Natural History Museum, Budapest derived from eight burial sites (see Map, Figure 1). These included seven juvenile crania and three adult crania from southern Hungary (Keszthely, Mözs and Mohacs), one juvenile and thirteen adult crania from the north (Velem-Szentvid, Rakoczifalva, Tiszavasvari, Hajdúnánás) and a juvenile cranium from Arad-Gáj (Romania). All samples come from the main regions of Hunnic settlements in Hungary and Romania (Sinor, 1990). The individual from AradGáj was placed with the Hungarian samples in Budapest and comes from Transylvania, which was ceded from Hungary to Romania in 1947. We describe these samples as Hungarian based on their current repository. 
We focused our analysis on the cranial vault as this is the region of the skull subject to bindings. In order to place landmarks and semi-landmarks for Procrustes analysis, the main criterion for sample inclusion was a sufficiently intact cranial vault. This allowed us to include several specimens where the cranial base was absent. However, several samples where the cranial vault was incomplete were deemed unsuitable for study. Thus, of 21 individuals with modified skulls from Keszthely-Fenékpuszta (Pap, 1985), 14 were available to be imaged but only eight were suitable to be included in this study. Mözs had over 40 modified skulls (Ódor, 2011), of which three were available, but one juvenile was suitable for study. Only single individuals were available to study from Mohacs, Tiszavasvari, Velem-Szentvid, and Arad-Gáj. These sites therefore permit as complete a representation of samples as was possible. Small sample sizes and poor subsampling across sites and age classes are universally acknowledged limitations in studying ontogenetic allometry in archeological and paleontological contexts, and are likely to produce results with lower statistical power (Brown and Vavrek, 2015). At the same time, ontogenetic series of modified crania provide a unique perspective for studying cultural modification as juvenile crania retain impressions of bindings placed in early childhood. Few previous studies have included such samples. We bear in mind the sampling limitations when interpreting our results and hope that additional studies with augmented samples may help to verify our findings.

\section{We included twenty-one modified adult crania from Georgia (Figure 2). The Georgian crania} came from the region of Mtskheta, studied at the Georgian National Museum's osteological

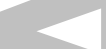
repository and the History and Ethnographic Institute of Tbilisi. Table 1 provides details on the sites, dental age, sex distribution and dating information for the samples. 
For all juveniles, we estimated age-at-death by the sequence of dental eruption (Buikstra and Ubelaker, 1994). The age of adults was estimated based on the degree of closure of ectocranial sutures (Meindl and Lovejoy, 1985). We assigned the following developmental stages to the dental eruption state: M0: first molars are unerupted, thus individuals below the age of 6; M1: first molars are in full occlusion, but second molars unerupted, thus individuals between the ages of six and 12; M2: second molars are in full occlusion, but third molars are unerupted and cranial sutures are unfused, thus individuals between the ages of 12 and 18; M3: third molars are in fullocclusion, thus individuals above the age of 18 . When the third molars were absent, we assigned individuals to the M3 stage based on cranial suture closure. We estimated sex from features of cranial robusticity (Ascadi and Nemeskeri, 1970). Georgia has a predominance of females with modified heads (76\% in our sample), but there is equal representation of males and females in Hungary. Our rationale for including variably represented samples in our study is explained below. The implications of the difference between Georgia and Hungary in age and sex representation of modified crania are addressed in the Discussion. We took the dates for the specimens from museum records based on archaeological contexts, or from radiocarbon dates, as stated in Table 1 . We selected specimens specific to the $4^{\text {th }}$ to $7^{\text {th }}$ c AD.

[Table 1 here]

[Figure 1 here]

[Figure 2 here]

\subsection{Data acquisition}

John Wiley \& Sons, Inc.

This article is protected by copyright. All rights reserved. 
We obtained cranial images using a NextEngine 3D laser scanner, which uses multiple laser stripes to image the object. We used the wide view, which has a resolution of $0.038 \mathrm{~cm}$ with 60 points per $\mathrm{cm}$. The surfaces of the specimens were digitalized using twelve landmarks and 251 semi-landmarks (Figure 3). We placed four landmarks in the midline and four bilaterally, making sure we captured locations in the sagittal, coronal and transverse planes (Table 2). We applied surface semi-landmarks manually to the template, approximately equidistant in concentric curves lateral to the sagittal curve. The lines of semi-landmarks incorporated fixed landmarks where possible (see Gunz et al., 2005). The number of semi-landmarks used were the minimum required to cover the cranial vault and decipher the shape differences while avoiding redundancies which could make subsequent analyses more complicated and time consuming (MacLeod, 2014; Gunz et al., 2005). We then projected the semi-landmarks onto the target cranial surfaces to which we had previously applied homologous fixed landmarks. We slid the semi-landmarks along tangents to the cranial surface to positions of maximal correspondence to the template bringing them into geometric correspondence with the homologous landmarks of the target specimens (Gunz et al., 2005). When cranial portions were missing, a thin plate spline interpolation was computed from the landmarks and semi-landmarks of the template and the incomplete specimen and mapped onto the incomplete specimen using the sliding step to mihimize bending energy between the two (Gunz and Mitteroecker, 2013). We then imported the information regarding the landmark configurations of the specimens into a virtual programme network (vpn) in Evan Toolbox for Generalized Procrustes superimposition and visualisation of the shape changes in the modified specimens by warping exemplar specimens along the principal axes of variation. 
[Table 2 here]

[Figure 3 here]

\subsection{Shape analysis}

After the cranial shapes had been standardised with Procrustes superimposition to eliminate differences in the size, orientation and position we used a principal components analysis to assess the relative shapes of the Georgian and Hungarian adult and the Hungarian juvenile specimens. The centroid of each configuration was calculated as the point at the mean values of the $x, y, z$ co-ordinates of all the landmarks. The centroid size was determined as the square root of the summed squared distances of each landmark to the centroid. Position was standardized by centring the centroids of each landmark configuration at zero. Orientation was standardized by rotating the landmark configurations to minimise the total distance between homologous landmarks. Size was standardized by scaling the centroid size of each landmark configuration to one. This left shape as the only parameter to be analysed (Zelditch et al., 2004). This procedure of standardizing position, orientation and size allowed us to include samples encompassing a range of cranial sizes and degrees of robusticity, thus individuals covering ontogenetic stages from juveniles to senile adult males and females. Individual Principal Component (PC) axes accounted for the shape variation described by multiple landmarks, reducing the number of variables to be assessed. The Evan Toolbox program derives the value of each PC from a variance-covariance matrix (see Zelditch et al., 2004). The first principal component axis (PC1) accounted for a major percentage of the shape variance, with subsequent PCs progressively less, until $100 \%$ of the shape variance had been included. We 
used plots of the first two PCs to demonstrate the relationship of the adult and juvenile crania from Hungary and those from Georgia.

To further examine group separation and get a quantitative assessment of the degree of crossover between the Georgian and Hungarian adult crania and between these and the Hungarian juvenile crania we subjected the PCs to a discriminant function analysis. We used a stepwise procedure to select the PCs that produced the best discrimination so that only variables that were highly significant in discriminating groups were selected in an iterative manner ( $p<0.01$ for F-value of variable to be entered, $p<0.10$ for F-value of a variable to be removed). No more than six PCs covering $56 \%$ of the total variance were used in the analysis.

We used regression analysis to explore the ontogenetic correlation between juvenile Hungarian cranial shape and adult Hungarian and Georgian cranial shape. To assess the fraction of shape variance explained by growth and development we regressed Procrustes distance against centroid size (as a measure of cranial growth), and dental age (as a measure of age), quantified by the R-squared value (Zelditch et al., 2004). Procrustes distance provides a measure of shape variation for each specimen and is the sum of the distances between homologous landmarks between each specimen and the reference specimen, after Procrustes superimposition. The reference specimen used was the one with the lowest value for the independent variable being assessed. Procrustes Distance was the dependent variable with centroid size and age serving as independent variables. The logarithm of centroid size was used because most of the variation in shape was seen in the smaller values of centroid size (Zelditch et al., 2004). 
The cranial shapes were then visualised in Evan Toolbox by warping the individual landmark configurations onto a template (Weber and Bookstein, 2012). Moving the cursor along a PC in the graph plotter progressively warps the underlying landmark configurations and generates a surface in the viewer, giving a clear picture of the shape variation described by each PC.

\section{Results}

\subsection{Principal component analysis}

Forty-six principal components capture the differences in cranial shape in the Hungarian and Georgian adult and Hungarian juvenile crania. The first two principal components account for $29 \%$ and $15 \%$ of the shape variation, respectively. Figure 4 plots the crania on the first two principal components. Convex hulls display the cut-off points between the groups. Example crania show the extent of shape variation. The scatter diagram shows wide variation in shape of the Georgian crania compared with the Hungarian adult and juvenile crania. The Georgian crania vary from long and low at the negative end of the first PC to narrow and tall at the positive end. The adult Hungarian crania have a relatively small range of shape variation. In spite of the small number of juvenile Hungarian crania the variation in shape is quite extensive. The Hungarian adult and juvenile crania cluster around PC2 and are characterized by postcoronal flattening and bulging parietals. Several Georgian crania also fall into this morphospace. [Figure 4 here]

\subsection{Discriminant Analysis}

John Wiley \& Sons, Inc.

This article is protected by copyright. All rights reserved. 
A step-wise discriminant analysis selected six principal PCs to provide the best separation with cross-validation (Table 3). When three groups, Hungarian juveniles, Hungarian adults and Georgian adults, were used in the analysis overall accuracy of classification was $93.5 \%(89.1 \%$ in cross-validation). When the procedure was repeated in an attempt to classify the Hungarian juveniles in a post-hoc manner based on the discriminant functions of the Hungarian and Georgian adults, six (67\%) of the Hungarian juveniles were attributed to Hungarian adults despite greater shape variation and sample size of the Georgian adults (Table 4). This shows similarity in cranial shape between the Hungarian juveniles and adults.

[Table 3 here]

[Table 4 here]

\subsection{Ontogenetic allometry}

An analysis of variance (ANOVA) showed significant correlation $(p<0.05)$ between Procrustes distance (PD), as consensus shape, cranial growth characterized by the natural logarithm of the centroid size (InCS), and dental age, as a proxy for development (Table 5). In a regression of cranial shape against cranial growth there was stronger linear relationship between Hungarian juvenile and adult crania, with an $\mathrm{R}^{2}$ value of 0.352 , than between Hungarian juvenile and Georgian adult crania, with an $\mathrm{R}^{2}$ of 0.269 . Figure 5 shows the scatter plot of PD against InCS for Hungarian juveniles of dental ages $\mathrm{MO}-\mathrm{M} 2$, Hungarian adults of $\mathrm{M} 3$ dental age (Figure $5 a$ ) and Georgian adults of M3 dental age (Figure 5b). The Hungarian juveniles and Georgian adults have strong variation in InCS, but not so the Hungarian adults. Dental age provides a stronger variable than InCS for simulating ontogenetic trajectory (Simons and Frost, 2016) and returned 
a stronger $\mathrm{R}^{2}$ correlation of 0.467 for the Hungarian juvenile and adult crania, than the Hungarian juvenile and Georgian adult crania, which returned an $\mathrm{R}^{2}$ of 0.363 (Table 5). A correlation of PD and dental age with $\ln C S$ as a covariate increased the correlation to $\mathrm{R}^{2}$ of 0.684 for the Hungarian juvenile and adult crania and $R^{2}$ of 0.61 for the Hungarian juvenile and Georgian adult crania. A plot of dental age against estimated marginal means of PD demonstrated that most shape change occurred during the period of rapid cranial growth, during the M0 - M1 dental age period (0-6 years), with further change occurring up to M2 (612 years), after which there was little change leading to M3 (above 18 years) (Figure 6).

Although the Georgian adults have a higher range and standard deviation in PD values (Figure 7), the mean PD values do not differ significantly between the Georgian and Hungarian adults.

Our results of stronger correlation between the Hungarian juveniles and adults in analyses of ontogenetic allometry should nevertheless be treated with caution given our relatively small sample of juveniles.

[Table 5 here]

[Figure 5 here]

[Figure 6 here]

[Figure 7 here]

\subsection{Warping in Evan Toolbox}

The shape differences in modified crania are revealed with Evan Toolbox by warping along the PC axes. The three-dimensional landmark configurations at each point are applied to a template 
which then displays the modified shape as denoted by PC1 and PC2 at that point. Warping along PC1 from +0.1 to -0.1 demonstrates the transition in shape from a simulated juvenile to a simulated adult cranium along that axis (Figure 8). The sagittal view shows that the frontal and occipital regions of Hungarian juvenile crania have a steep angle as a result of the anteroposterior binding. These areas become less steep and more rounded in the adult crania after the age when the binding has ceased. The axial view reveals the biparietal diameter to be wide in the juvenile crania as a result of the second vertical binding producing compensatory expansion in the parietal regions but this is reduced in the adult crania. Similarly, an expansion of the postorbital region due to the vertical binding is noted in the juvenile crania causing a reduction in the postorbital constriction in these as compared to the adult crania. While the warping is yisualized on a template in Evan Toolbox, the ontogenetic shape changes can also be appreciated by comparing photographs of actual Hungarian juvenile and adult crania, as shown in Figure 9.

[Figure 8 here]

[Figure 9 here]

The depressions on the cranial bones allow us to interpret how the bindings were applied to produce the modified shapes. We selected four crania from Georgia and four from Hungary to depict the variety of modified cranial shape (Figure 10). Georgian crania such as 1880 and 2383 appear to be modified by one or two encircling bindings extending from the frontal to the occipital regions. Grooves from the bandages are visible on the frontal, parietal and occipital bones. This form of modification, termed the annular type (Dembo and Imbelloni, 1938; Zhirov, 
1940) is maintained by placing tight bandages high or low on the frontal and occipital regions, which results in the head appearing tall and domed or low and sloping. Specimen 1958 on Figure 4 also demonstrates this modification. Most of these crania are visually striking. There is marked compensatory expansion superiorly or obliquely posteriorly allowing the brain to grow towards the uncompressed regions of the skull (Tiesler, 2014). Other crania from Georgia, such as 1618 and 2402 (Figure 10) are flattened in the region of bregma, suggesting the presence of a second binding. The obliquely oriented frontal and vertically oriented occipital in 1618 may have been produced by stiff compression boards or bandages, which may be described as coronal-occipital (Zhirov, 1940) or tabular modification (Dembo and Imbelloni, 1938). A postcoronal bandage ensures that the head is not too tall. The Georgian crania flattened in the region of bregma are similar to those from Hungary (Figure 10, 11885, 20092613, 337493, 355515). These are modified with two bindings, the first placed antero-posteriorly and the second extending from the post-coronal region over the temporal bones bilaterally to the angle of the mandible. This produced flattening of the frontal bone with a fairly steep gradient, flattening of the occipital region, as well as post-coronal flattening and depressions of the temporal bones laterally with bilateral compensatory expansion of the parietal bones in the line of the binding. Crania such as 20092613 and 337493 show the typical uniform shape for the Hungarian crania (see other examples on Figure 4). There are, however, some severely modified crania in this group. The juvenile cranium 118855 has strong impressions of annular and coronal bindings resulting in a bilobed appearance and bulging parietals. The adult specimen 35515 similarly has a bilobed appearance, albeit less severe. This individual also displays an oblique frontal and vertical occipital region and deep marks from pressure pads on

John Wiley \& Sons, Inc.

This article is protected by copyright. All rights reserved. 
the parietal bosses. The groove from the post-bregmatic binding is also clearly visible. Figure 11 shows these crania in superior view

[Figure 10 here]

[Figure 11 here]

\section{Discussion}

Our study demonstrates the utility of a geometric morphometric approach in detecting shape differences in intentionally modified crania from Georgia and Hungary and between juvenile and adult Hungarian crania. Using surface landmarks and semi-landmarks from three dimensions, we were able to show that crania from Hungary during the Migration Period were modified in a uniform manner compared with modified crania from Georgia. This result reinforced our previous findings from two-dimensional outline analysis (Mayall et al., 2017).

Warping the mean cranial shape along the principal component axes revealed the transformation from the juvenile to adult modified crania associated with anterior-posterior and superior-inferior bindings resulting in a bilateral expansion in the region of the parietals (Figure 8). The bindings in the juveniles leave exaggerated depressions in the pathway of the bandages (Figures 9, 10,11). This is because the cranial bones in juveniles are soft and unilaminar and the bones are not completely mineralised. The trabecular structure with the diploe in between the outer tables is not visible until the fourth year (Rice, 2008; Standring, 2008; Lieberman, 2011). As a result, juvenile cranial bones have greater plasticity and are susceptible to alteration from compression. The pathway of the bandages as seen in sagittal 
and superior views supports our previous hypothesis (Mayall et al., 2017) that cranial modification in Hungary during the Migration Period was predominantly done using two bandages. Pap $(1984,1985)$ has previously described this type of modification for the crania from Hungary.

The regression analyses of the Hungarian adult and juvenile modified crania confirmed that the period of greatest cranial shape variation corresponds to the early period of life during the time of rapid cranial growth. This is also the period in which bindings are applied to the crania. Tiesler (2014) states that cranial modification is possible only during the period of active cranial growth, principally during the first two years of life as after this time growth of the cranial vault occurring at the sutures ceases. By incorporating ontogenetic series of modified crania into our study, we find, however, that we are able to offer a slightly different perspective. Limited cranial shape variation across several Hungarian sites and age classes, and over a long period of time suggests that we are observing a consistent pattern. Although larger sample sizes for each age group and site are needed to substantiate our findings, we see rapid shape changes to the cranial vault from birth to the eruption of first molars at six years (Figure. 6). Following this, there are slight shape changes until the eruption of the second molar at about 12 years, and then further changes take place until the eruption of third molars in adulthood. Our observations fit the growth trajectory of the cranial vault paralleling the growth of the brain (Lieberman, 2011). By the time of the eruption of the first molar at around six years, 95 percent of brain growth is complete, followed by slower growth of the vault during the juvenile period until the eruption of the second molar and more rapid growth until the eruption of the third molar in adolescence (Lieberman, 2011). Ross and Williams (2010) found small changes in 
cranial vault dimensions from the age of 14 to 20 , but significant vault changes in the 25 to 40 year range. Previous studies also found considerable variation in the pattern and degree of cranial suture closure at the endocranial and ectocranial surfaces, with sutures sometimes remaining patent even into the third and fourth decades of life (Albert et al., 2007; Baer, 1956; Kendrick and Risinger, 1967; Key et al., 1994; Perizonius, 1984; Thompson and Kendrick, 1964; Vijaya Kumar et al., 2012). There is also evidence that the biological process of bone absorption and deposition remodel the cranial bones and change the thickness and shape of the cranial vault well into the sixth decade of life (Albert et al., 2007; Behrents, 1990; Enlow, 1990; Israel, 1968). It is not clear when the bandages were removed from the juvenile modified skulls in the Migration Period of Europe, but it is apparent that once the pressure from the bindings was released the deformed skull continued to grow, reverting to its normal, unmodified shape to some extent. This could explain why markings from the bindings are not as deep on the adult skulls as on the juveniles.

This study serves to highlight the role of intentional cranial modification as a cultural practice to denote social identity during the Migration Period of Europe. This is seen in the stylistic homogeneity in cranial modification in Hungary. The correlation we found between juvenile and adult modified cranial shape is unlikely to be due to genetic affiliation because diverse socio-cultural groups were present in Hungary during the Migration Period. Historical sources mention the presence of Germanic groups, including Goths, Gepids, Langobards, Indo-Iranian nomadic tribes such as Sarmatians and Alans, pre-existing Romanised populations, as well as the Huns, who arrived in Hungary around 370 AD from the East and were themselves a 
conglomeration of Turkic and Scytho-Sarmatian groups (Czeglédy, 1983; Kim, 2013; Hancock, 2004; Kelly, 2015; Sinor, 1990; Vaissière, 2015).

Putting together the historical references and archaeological evidence it is reasonable to assume that the Huns promulgated the practice of cranial modification in the region at this time. Their arrival in the Carpathian basin marks a dramatic and definitive turning point in the history of Hungary, the Roman Empire and Europe (Kim, 2013; Sinor, 1990), setting in the motion the great migrations of the Germanic and Eurasian nomads and ultimately destabilising the Roman Empire (Halsall, 2005, 2007; Heather, 2015). While historians are unclear on whether the Huns picked up the practice on their journey to Europe from other groups such as the Alans, or carried the practice from their roots in Mongolia and Inner Asia, it is certain that they had modified heads by the time they arrived in the Pontic steppe (Czeglédy, 1983;

Maenchen-Helfen, 1958, 1973; Sinor, 1990). Upon their arrival, the practice became extremely prevalent in Hungary, modified crania making up to 80 percent of the crania in grave sites during the Migration Period (Fóthi, 2000; Hackenbeck, 2009; Kiszely, 1978; Paap, 1984, 1985; Torres-Rouff and Yablonsky, 2005). Although the political dominion of the Huns in Hungary was fairly short-lived, from about the 370s to the 460s (Kim, 2013; Vaissière, 2015), the practice of cranial modification in Hungary continued at least until the $7^{\text {th }} c A D$ under the political sway of other nomadic groups such as the Goths, Gepids, Langobards, and Avars (Molnár et al., 2014). The practice was widely adopted and maintained within the local community in Hungary as is evident from the incidence of modified crania from all age groups, neonates to senile adults, and an equal representation of males and females. It appears that several social groups in the region shared a social identity by following the same style of cranial modification over nearly 
three centuries despite political turnover. This attests to the influence of the Huns in consolidating this identity. The influence of the Huns long after their official political power had declined can best be appreciated if we consider that Western and Byzantine chroniclers anachronistically attributed several later events in the history of Europe and Hungary to the Huns (Czeglédy, 1983; Sinor, 1990).

Cranial modification in the Mtskheta region of Georgia in the Migration Period provides a counterpoint to the practice in Hungary. There are examples of modified heads in the Bronze Age, but these are sporadic and isolated compared with the proliferation after the $4^{\text {th }} c A D$, when modified crania make up about $24 \%$ of the crania from grave sites in Mtskheta. The increase in incidence can reasonably be associated with the Migration Period, but the diversity in modified cranial shape compared with Hungary suggests that a distinct set of social influences were operating in Georgia at this time. Indeed, historical references are equivocal about the presence of Huns in Georgia, but the presence of Alans and Sarmatians is consistently recorded (Alemany, 2000; Furtwängler et al., 2008; Rapp, 2003; reviewed in Mayall et al., 2017). Alans and Sarmatians were assimilated into the Hunnic ranks in Hungary (Hancock, 2004; Sinor 1990), but in Georgia the variation in modified cranial shape may suggest that they were forging a distinct social identity. The Alans eventually formed the kingdom of Alania (presentday Ossetia) in northern Georgia (Borjian, 2006). Different styles of modification among groups in close proximity highlight the value of ethnicity as "a social construct used to amplify cultural distinctions that are overlain on biologically similar populations" Torres-Rouff and Yablonsky, 2005: 3). The presence of predominantly adult females with modified heads and the absence of modified heads in the large sample of juveniles is difficult to interpret, but suggests that cranial 
modification was a non-local practice in Mtskheta and the females were migrants who did not extend the practice of cranial modification to the next generation. Hackenbeck (2009) similarly postulated the practice of female exogamy for Migration Period sites in Germany, where there is predominance of females and absence of juveniles with modified heads. Further studies involving cultural artefacts, genetic material, and strontium and oxygen isotope ratios may help to determine the original location of these individuals.

The social significance of cranial modification in the Migration Period of Europe is similar to that in South America and Mesoamerica, where cranial modification was practised for several thousand years (Tiesler, 2012). Researchers were able to identify temporal changes in modification styles, evidence for solidarity in tight regional groups where there was little variation in cranial shapes, and the presence of mixed urban groups where diverse modification styles provided fluid boundaries between groups (Blom, 2005; Perez, 2007; Torres-Rouff, 2002).

\section{Conclusions}

The Migration Period is acknowledged to be a formative period in the history of Eurasia.

Historians have largely relied on contemporary historical and linguistic sources to reconstruct this time-period with little reference to the archaeological record (Frachetti, 2008; Goffart, 2006). The bioarchaeological evidence as portrayed by the distinctive skeletal mark of modified crania adds a new dimension to understanding social interactions during this time-period (Anke, 1998; Hakenbeck, 2009; Huck, 2007; Kiszely, 1978). In this study, surface analysis helped to provide a more comprehensive assessment of the cranial shape differences between regions, which confirmed that Georgian and Hungarian crania were modified using different methods. 
By incorporating juvenile crania in the study, we demonstrated that the Hungarian crania were modified using a uniform technique of two bandages, which constrained cranial shape, whereas Georgian crania were bound using several techniques, which resulted in a variety of cranial

shapes. Regression analyses confirmed that the major shape alteration occurred during the first few years of life, during the period of rapid cranial growth but there was some reversal to the unmodified shape in adulthood after the bindings had been removed. Intentional cranial modification was widespread in Europe during the $4^{\text {th }}$ to $7^{\text {th }}$ centuries and was used as a permanent and highly visible form of social identity.
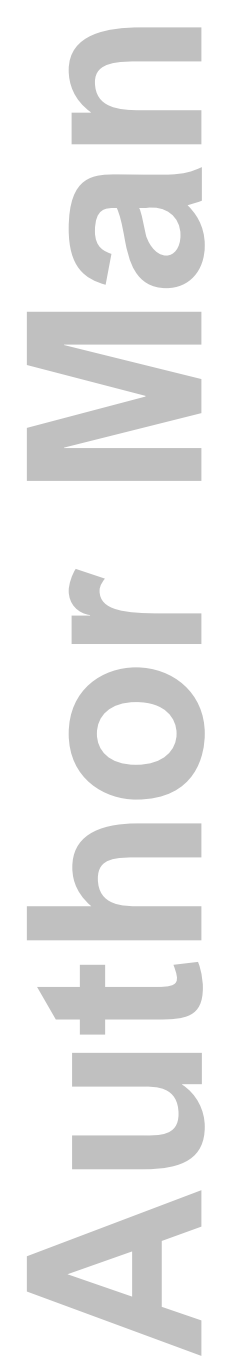


\section{Acknowledgements}

This work was supported partially by the American Association of Physical Anthropologists Professional Development Grant. The research was carried out as part of the Georgian Australian Investigations in Archaeology (GAIA). We thank late Prof. Antonio Sagona of the University of Melbourne and Prof. David Lordkipanidze of the Georgian National Museum for setting up the collaboration and inviting VP to undertake the physical anthropological analysis. The cranial material referenced in the paper is archived in the following museums: Hungarian Museum of Natural History, Budapest; The Georgian National Museum, Tbilisi; Ivane Javakhishvili institute of History and Ethnology, University of Tbilisi. We thank the curators of the museum for access to the cranial material. We thank Assoc. Prof. Christina Bryant of the University of Melbourne for commenting on an earlier version of the paper, and anonymous reviewers for their critical review, which strengthened the paper. Both authors contributed equally to conceptualizing the paper and developing the methodology. PM wrote the original draft of the paper; VP reviewed and edited the paper. 


\section{References}

Albert, A., Ricanek, K., Patterson, E. (2007). A review of the literature on the aging skull and face: Implications for forensic science research and applications. Forensic Science International, 172, 1 -9.

Alemany, A. (2000). Sources on the Alans. Handbook of Oriental Studies, Sect. 8: Central Asia, Vol. 5. Leiden: Brill.

Anke, B. (1998). Studien zur reiternomadischen Kultur des 4. Bis 5. Jahrhunderts. Teil 1: Katalog und Tafeln. Beiträge zur Ur- und Frühgeschichte Mitteleuropas. 8). Weissbach: Beier \& Beran.

Ascadi, G., \& Nemeskeri, J. (1970). History of Human Lifespan and Mortality. Budapest: Akademiai Klado.

Baer, M. (1956). Dimensional changes in the human head and face in the third decade of life. American Journal of Physical Anthropology, 14 (4), 557 - 575.

Behrents, R. (1990). Adult facial growth. In Enlow D. (Ed.), Facial Growth (pp. 423 - 443).

Philadelphia: W. B. Saunders Company.

Blom, D. (2005). Embodying borders: Human body modification and diversity in Tiwanaku society. Journal of Anthropological Archaeology, 24, 1 - 24.

Borjian, H. (2006). Review of Sources on the Alans: A Critical Compilation by Agustí Alemany. Journal of American Oriental Society. 126 (4), 601 - 604. 
Buikstra, J., \& Ubelaker, D. (1994). Standards for data collection from human skeletal remains. Arkansas Archaeological survey research series No.44, Fayetteville, Arkansas.

Czeglédy, K. (1983). From East to West: The Age of Nomadic Migrations in Asia. Archivum Eurasiae Medii Aevi. 3, 25 - 125.

Dembo, A., \& Imbelloni, J. (1938). Deformaciones intencionales del cuerpo humano de Cara' cter Étnico. J Anesi, Buenos Aires.

(a)

Dingwall, E. (1931). Artificial Cranial Deformation. London: John Bale Sons \& Daniellson, Ltd.

Enlow, D. (1990). (Ed). Facial Growth. W. B. Saunders and Company, Philadelphia.

Fóthi, E. (2000). Anthropological conclusions of the study of Roman and Migration periods. Acta Biologica Szegeiensis 44, 87 - 94.

Frachetti, M. (2011). Migration concepts in Central Eurasian Archaeology. Annual Review of Anthropology 40, $195-212$.

Furtwängler, A., Gagoshidze, I., Löhr, H., Ludwig, N. (2008). (Eds). Iberia and Rome: The excavations of the palace at Dedoplis Gora and the Roman influence in the Caucasian kingdom of Iberia. Beier \& Beran: Langenweißbach.

Gerszten, P. (1993). An investigation into the practice of cranial deformation among the preColumbian peoples of Northern Chile. International Journal of Osteoarchaeology 3, 87 - 
mutilation. Neurosurgery 37(3), $374-382$.

Goffart, W. (2006). Barbarian Tides: The Migration Age and the Later Roman Empire.

Philadelphia: University of Pennsylvania Press.

Gunz, P. Mitteroecker, P. (2013). Semilandmarks: a method for quantifying curves and surfaces.

Hystrix, the Italian Journal of Mammalogy 24 (1), 103-109.

Gunz, P., Mitteroecker, P., Bookstein, F. (2005). Semilandmarks in three dimensions. In Slice D.

(Ed.) Modern Morphometrics in Physical Anthropology (pp. 73 - 97). New York: Kluwer Academic/Plenum Publishers.

Hakenbeck, S. (2009). 'Hunnic' modified skulls: physical appearance, identity and the transformative nature of migrations. In Sayer D, Williams H (Eds). Mortuary Practices and Social Identities in the Middle Ages (pp. 64-80). Exeter: University of Exeter Press.

Halsall, G. (2005). The Barbarian Invasions. In Fouracre P (Ed.) The New Cambridge Medieval History (pp. 35 - 55). Cambridge: Cambridge University Press.

Halsall, G. (2007). Barbarian Migrations and the Roman West. Cambridge: Cambridge University Press.

Hancock, B. (2004). Alani gain power. In Chavalas M. (Ed.) Great Events from History: The Ancient World, Prehistory-476 c.e. Massachusetts: Salem Press Encyclopedia. 
Heather, P. (2015). The Huns and Barbarian Europe. In M Maas (Ed.) The Cambridge Companion to the Age of Attila (pp. 209 - 229). Cambridge: Cambridge University Press.

Heinrich-Tamaska, O., \& Schweissing, M. (2011). Strontiumisotopen und

Radiokarbonuntersuchungen am arthropologischen Fundmateriel von Keszthely-

Fenékpuszta: Ihr Aussagepotenziel zur fragen der Migration und Chronologie . In O.

Heinrich-Tamaska. (Ed.) Keszthely-Fenékpuszta im Kontext spätantiker

Kontinuitätsforschung zwischen Noricum und Moesia (pp. 457 -474). Budapest: Verla Marie Leidorf $\mathrm{GmbH}$.

Huck, T. (2007). Thuringer und Hunnen. In Historisches Museum der Pfalz Speyer (Ed.) Attila und die Hunnen (pp.323 - 331). Stuttgart: Konrad Theiss Verlag.

Hukki, J., Saarinen, P., Kangasniemi, M. (2008). Single suture craniosynostosis: Diagnosis and Imaging. In D. Rice (Ed.) Craniofacial Sutures: Development, Disease and Treatment (pp.

\section{9 - 90. Basel: Karger AG.}

Israel, H. (1968). Continuing growth in the human cranial skeleton. Archives of Oral Biology 13, $133-137$.

Kim, HJ. (2013). The Huns, Rome and the Birth of Europe. Cambridge: Cambridge University Press.

Kelly, C. (2015). Neither conquest nor settlement: Attila's empire and its impact. In Mass, M.

(Ed.) The Cambridge Companion to the Age of Attila (pp. 193 - 208). Cambridge:

Cambridge University Press.

John Wiley \& Sons, Inc. 
Kendrick, G., Risinger, H. (1967). Changes in the anteroposterior dimensions of the human male skull during the third and fourth decade of life. The Anatomical Record 159, 77 - 82.

Key, C., Aiello, L., Molleson, T. (1994). Cranial suture closure and its implication for age estimation. International Journal of Osteoarchaeology 4, 193 - 207.

Kiszely, I. (1978). The Origins of Artificial Cranial Deformation in Eurasia from the Sixth millennium BC to the seventh century AD. British Archaeological Reports, International Series (Supplementary) 50.

Vijaya Kumar, A., Agarwal, S., Bastia, B., Shivaramu, M., Honnungar, R. (2012). Fusion of skull vault sutures in relation to age - a cross sectional post-mortem study done in $3^{\text {rd }}, 4^{\text {th }}$ and $5^{\text {th }}$ decades of life. Journal of Forensic Research 3, 173. DOI:10.4172/2157-7145.1000173.

Lieberman, D. 2011. The evolution of the human head. Cambridge, Massachusetts: Belknap Press of Harvard University Press.

MacLeod, N. (2014). Semilandmarks and Surfaces Paleomath 101. The Palaeontological Association Newsletter. http://www.palass.org/modules.php?name=palaeo math.

Mayall, P., Pilbrow, V., Bitadze, L. (2017). Migrating Huns and modified heads: Eigenshape analysis comparing intentionally modified crania from Hungary and Georgia in the Migration Period of Europe. PLoS ONE 12(2), e0171064.

Doi:10.1371/journal.pone.0171064.

Maenchen-Helfen, O. (1958). Review. Joachim Werner J. 1956. Beitrage zur Archaologie des Attila-Reiches. Speculum 33, $159-166$. 
Maenchen-Helfen, O. (1973). The World of the Huns. Berkeley: University of California Press. Meindl R., Lovejoy C. (1985). Ectocranial suture closure: A revised method for the determination of skeletal age at death based on the lateral-anterior sutures. American Journal of Physical Anthropology 68, $57-66$.

Molnár M., János, I., Szucs, L., Szathmáry, L. (2014). Artificially deformed crania from the HunGermanic Period $\left(5^{\text {th }}-6^{\text {th }}\right.$ century AD) in northeastern Hungary: historical and morphological analysis. Neurosurgery Focus 36, 1 - 9.

Müller, R. (2003). The Romanised populations in the $5^{\text {th }}$ to $6^{\text {th }}$ centures. In Visy, Z. (Ed.)

Hungarian Archaeology at the Turn of the Millennium (pp 289-291). Ministry of National Cultural Heritage. Budapest: Teleki László Foundation.

Ódor, J. (2011). The 5th century cemetery and settlement at Mözs (Tolnar County, Hungary) in Keszthely-Fenekpuszta. In: Heinrich-Tamaska O, editor. Keszthely-Fenékpuszta im Kontext spätantiker Kontinuitätsforschung zwischen Noricum und Moesia (pp. 347-359). Budapest: Verla Marie Leidorf GmbH.

Pap, I. (1984). Data to the Problem of Artificial Cranial Deformation, Part 2. Annales HistoricoNaturales Musei Nationalis Hungarici 76, 335 - 350.

Pap, I. (1985). Data to the problem of artificial cranial deformation, Part 3. Annales HistoricoNaturales Musei Nationalis Hungarici 77, 281 - 289.

Perez, S. (2007). Artificial cranial deformation in South America: a Geometric Morphometrics approximation. Journal of Archaeological Science 34, 1649 - 1658. 
Perizonius, W. (1984). Closing and non-closing sutures in 256 crania of known age and sex from Amsterdam (A.D. 1883 - 1909). Journal of Human Evolution 13, 201 - 216.

Rapp, S. (2003). Studies in Medieval Georgian Historiography: Early Texts and Eurasian Contexts. Peeters Press, Leuven.

Rice, D. (2008). Developmental anatomy of craniofacial sutures. In D. Rice (Ed.) Craniofacial Sutures: Development, Disease and Treatment (pp. 1 - 21). Basel: Karger AG.

Ross, A., Williams, S. (2010). Craniofacial Growth, Maturation, and Change: Teens to Midadulthood. The Journal of Craniofacial Surgery 21, 458-461. DOI: 10.1097/SCS.0b013e3181cfea34

Sagona, A., Nikolaishvili, V., Sagona, C., Ogleby, C., Pilbrow, V., Briggs, C., Giunashvili, G., Manjegaladze, G. (2010). Bridging two continents: Renewed investigations at Samtavro, Georgia. TUBA-AR-Turkish Academy of Sciences Journal of Archaeology 13, 313 - 334.

Schmidt, B. (1987). Das Konigreich der Thuringer und seine Provinzen. In W. Menghin, T. Springer \& E. Wamers (Eds.) Germanen, Hunnen und Awaren (pp. 471-512). Nurnberg:

Germanisches Nationalmuseum.

Simons, E., Frost, S. (2016). Constructing cranial ontogenetic trajectories: A comparison of growth, development, and chronological age proxies using a known-age sample of Macaca mulatta. American Journal of Physical Anthropology 161, 296 - 308. DOI

10.1002/ajpa.23031

John Wiley \& Sons, Inc.

This article is protected by copyright. All rights reserved. 
Sinor, D. (1990). The Hun Period. In Sinor, D. (Ed.) The Cambridge History of Early Inner Asia (pp. 177-205). Cambridge: Cambridge University Press.

Standring, S. (2008). (Editor-in-Chief.) Gray's Anatomy, The Anatomical Basis of Clinical Practice, Fortieth edition. United Kingdom: Elsevier.

Thompson, J., Kendrick, G. (1964). Changes in the vertical dimensions of the human male skull during the third and fourth decades of life. The Anatomical Record 150, $209-214$.

Tiesler, V. (2012). Studying cranial vault modifications in ancient Mesoamerica. Journal of Anthropological Sciences 90, $33-58$.

Tiesler, V. (2014). The Bioarchaeology of Artificial Cranial Modifications. Springer: New York.

Torres-Rouff, C. (2002). Cranial vault modification and ethnicity in middle horizon San Pedro de Atacama, Chile. Current Anthropology 43, 163 - 171.

Torres-Rouff, C. \& Yablonsky, L. (2005). Cranial vault modification as a cultural artefact: a comparison of the Eurasian steppes and the Andes. HOMO - Journal of Comparative Human Biology 56, 1-16.

Tóth, A. (2003). History of the Huns. In Visy, Z. (Ed.) Hungarian Archaeology at the Turn of the Millennium (pp 294 - 298). Ministry of National Cultural Heritage. Budapest: Teleki László Foundation. 
Vaissière, E. (2015). The steppe world and the rise of the Huns. In Mass, M. (Ed.) The Cambridge Companion to The Age of Attila (pp. 175 - 192). Cambridge: Cambridge University Press.

Vinicius, L. (2005). Human encephalization and developmental timing. Journal of Human Evolution 49, $762-776$.

Vijaya Kumar, A., Agarwal, S., Bastia, B., Shivaramu, M., Honnungar, R. (2012). Fusion of skull vault sutures in relation to age - a cross sectional post-mortem study done in $3^{\text {rd }}, 4^{\text {th }}$ and $5^{\text {th }}$ decades of life. Journal of Forensic Research 3, 173. DOI:10.4172/2157-7145.1000173.

Weber, G. \& Bookstein, F. (2012). Evan Toolbox - Introductory Manual. University of Vienna.

Werner, J. (1956). Beiträge zur Archäologie des Attila-Reiches. Bayerische Akadamie der Wissenschaften. Philosophisch-historische Klasse. Abhandlungen. N.F. XXXV111 A. Munchen Verlag der Bayerischen Akadamie der Wissenschaften.

Zelditch, M., Swiderski, D., Sheets, H., Fink, W. (2004). Geometric Morphometrics for Biologists: A Primer. San Diego: Elsevier Academic Press.

Zhirov, E. (1940). Ob iskusstvennoi deformatsii golovi. (Artificial deformation of the head). In Kratkie Soobsheniz Instituta Material 'Noi Kul' turi. Vip. VIII. AN SSSR, Moscow.

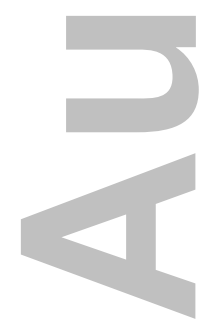




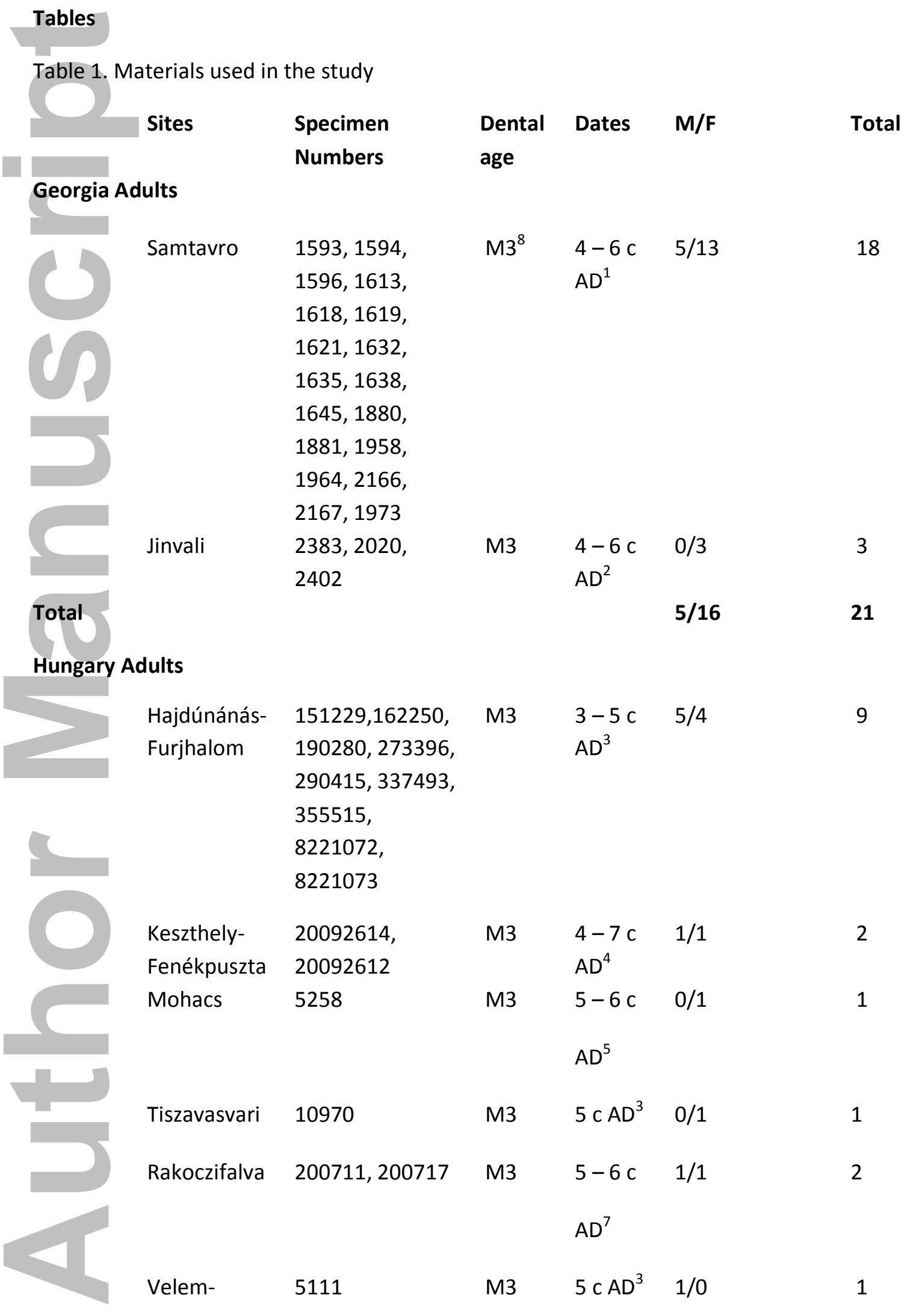




\section{Szentvid}

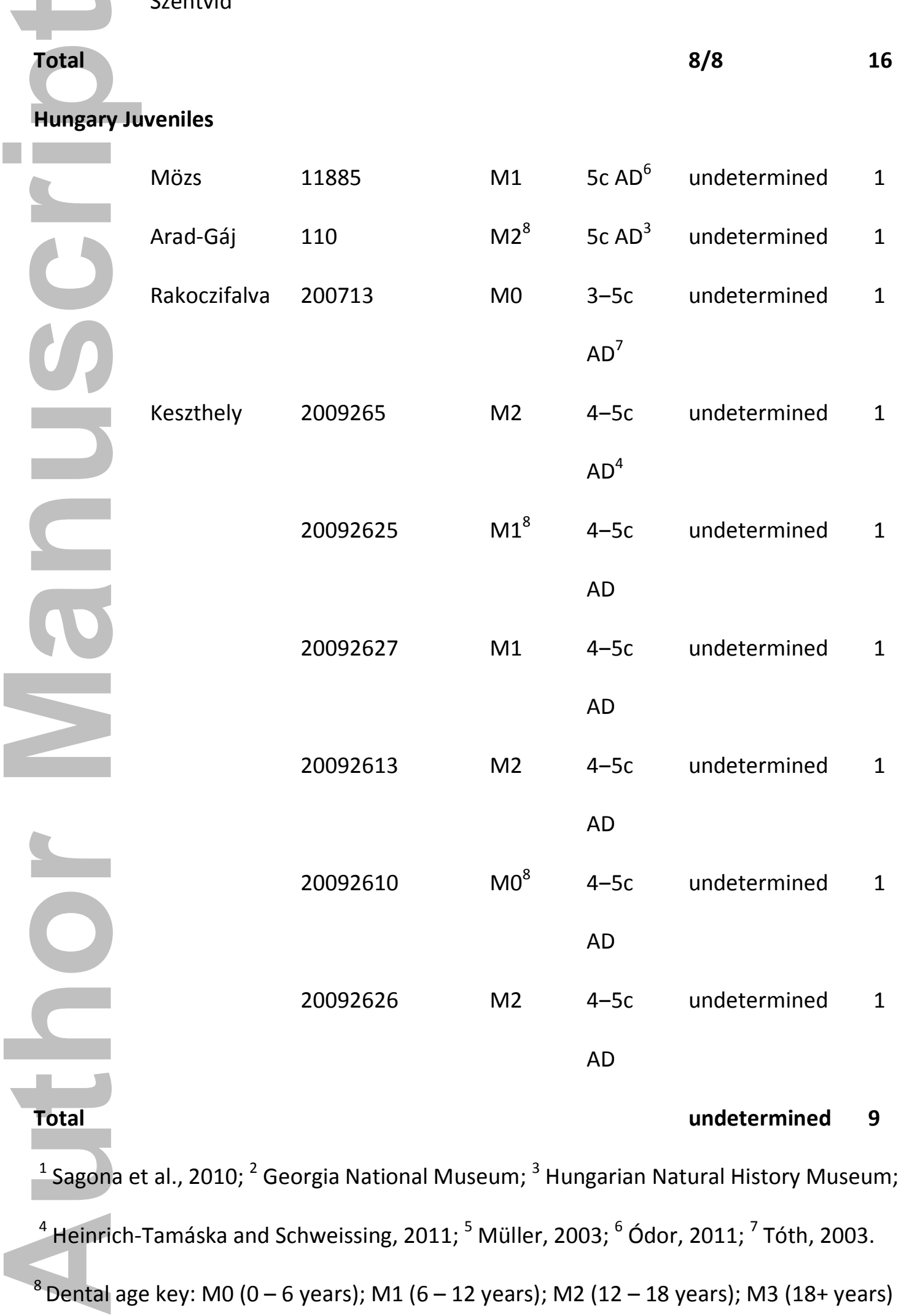

John Wiley \& Sons, Inc.

This article is protected by copyright. All rights reserved. 
Table 2. Cranial landmarks used in this study

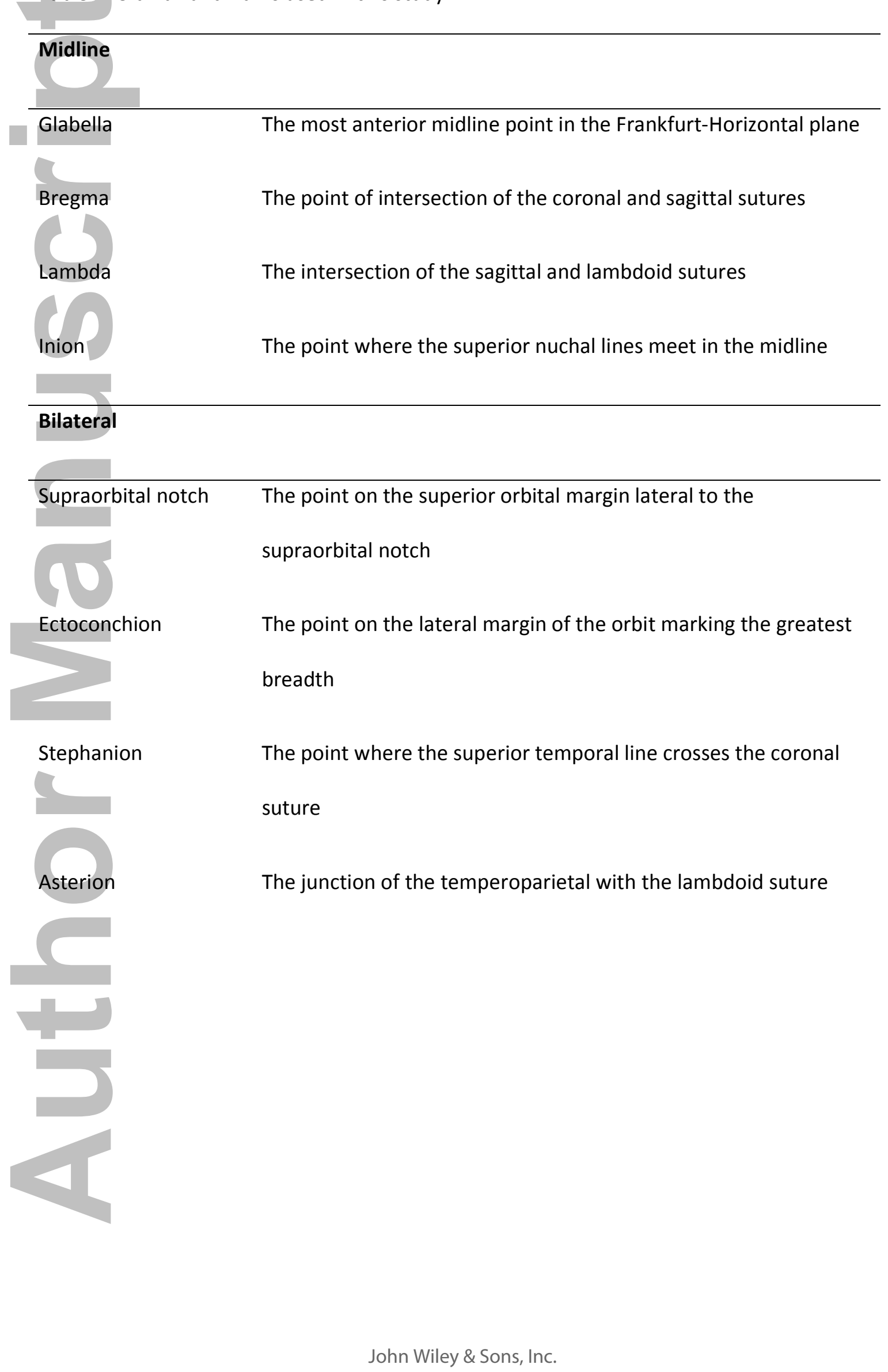

This article is protected by copyright. All rights reserved. 
Table 3. Discriminant analysis classification accuracy with cross-validation

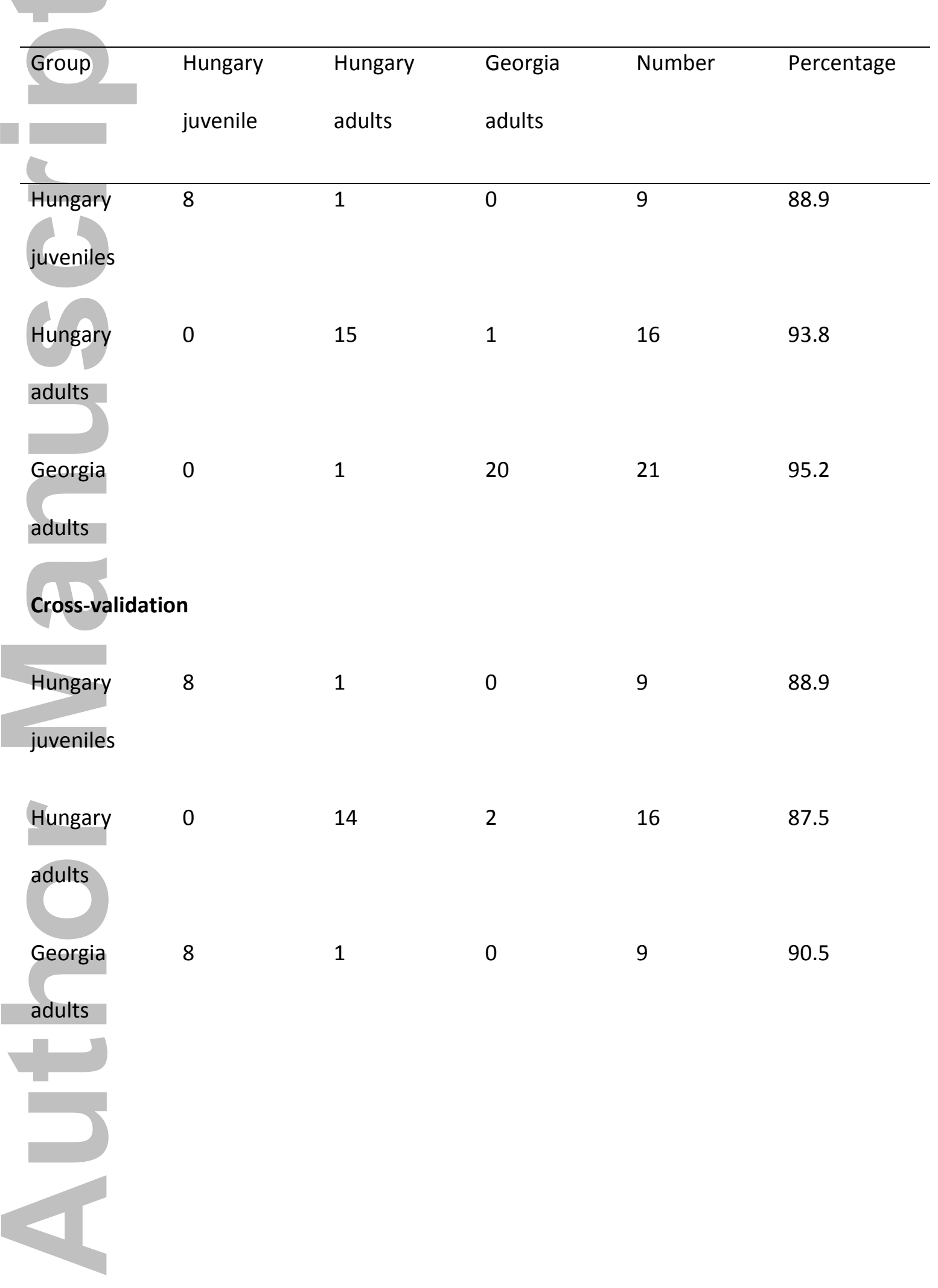

John Wiley \& Sons, Inc.

This article is protected by copyright. All rights reserved. 
Table 4. Discriminant analysis classification accuracy, with Hungarian juveniles classified

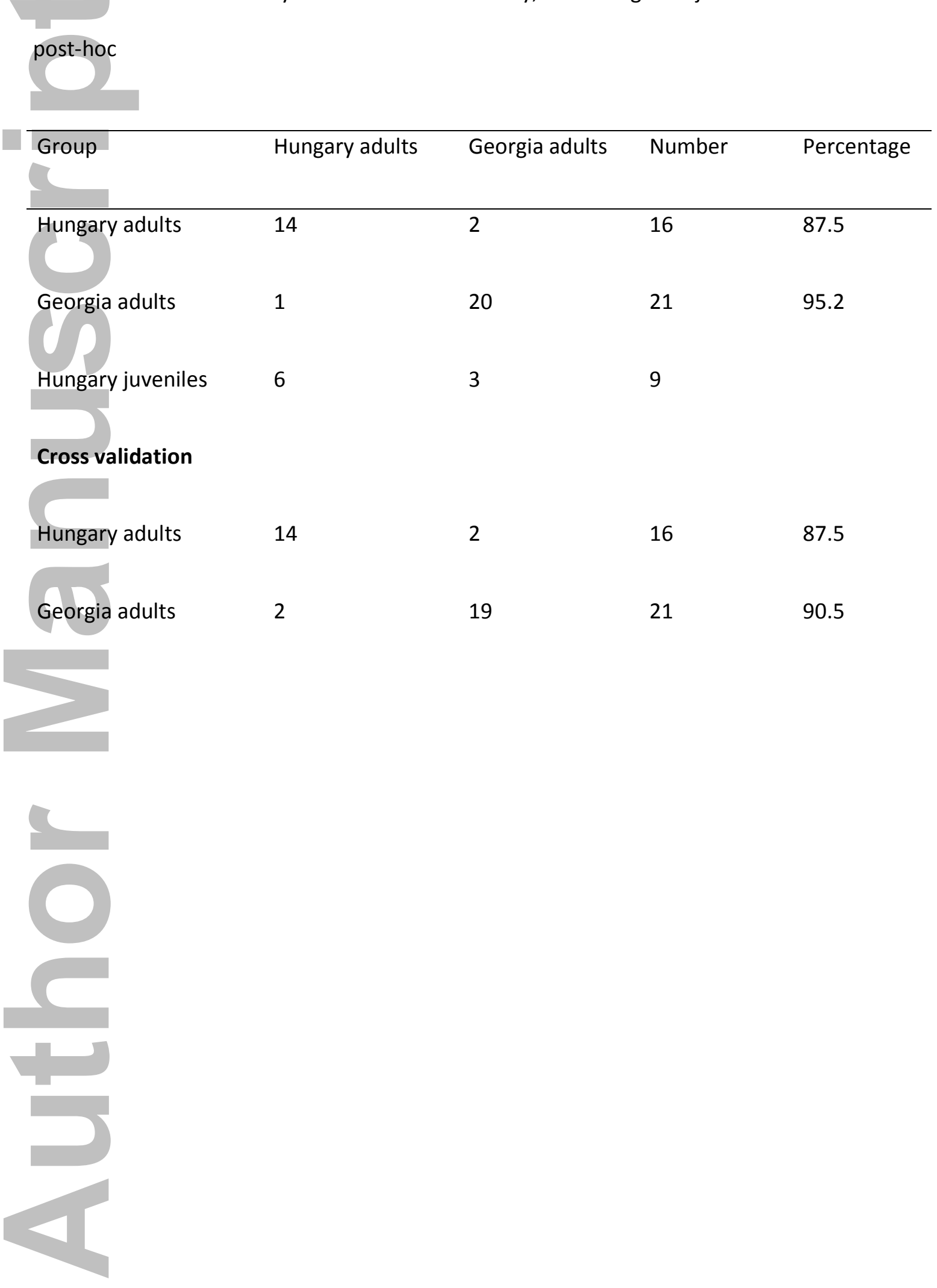

John Wiley \& Sons, Inc.

This article is protected by copyright. All rights reserved. 
Table 5. Correlation between Procrustes distance as dependant variable and proxies for ontogenetic trajectories as independent variables.

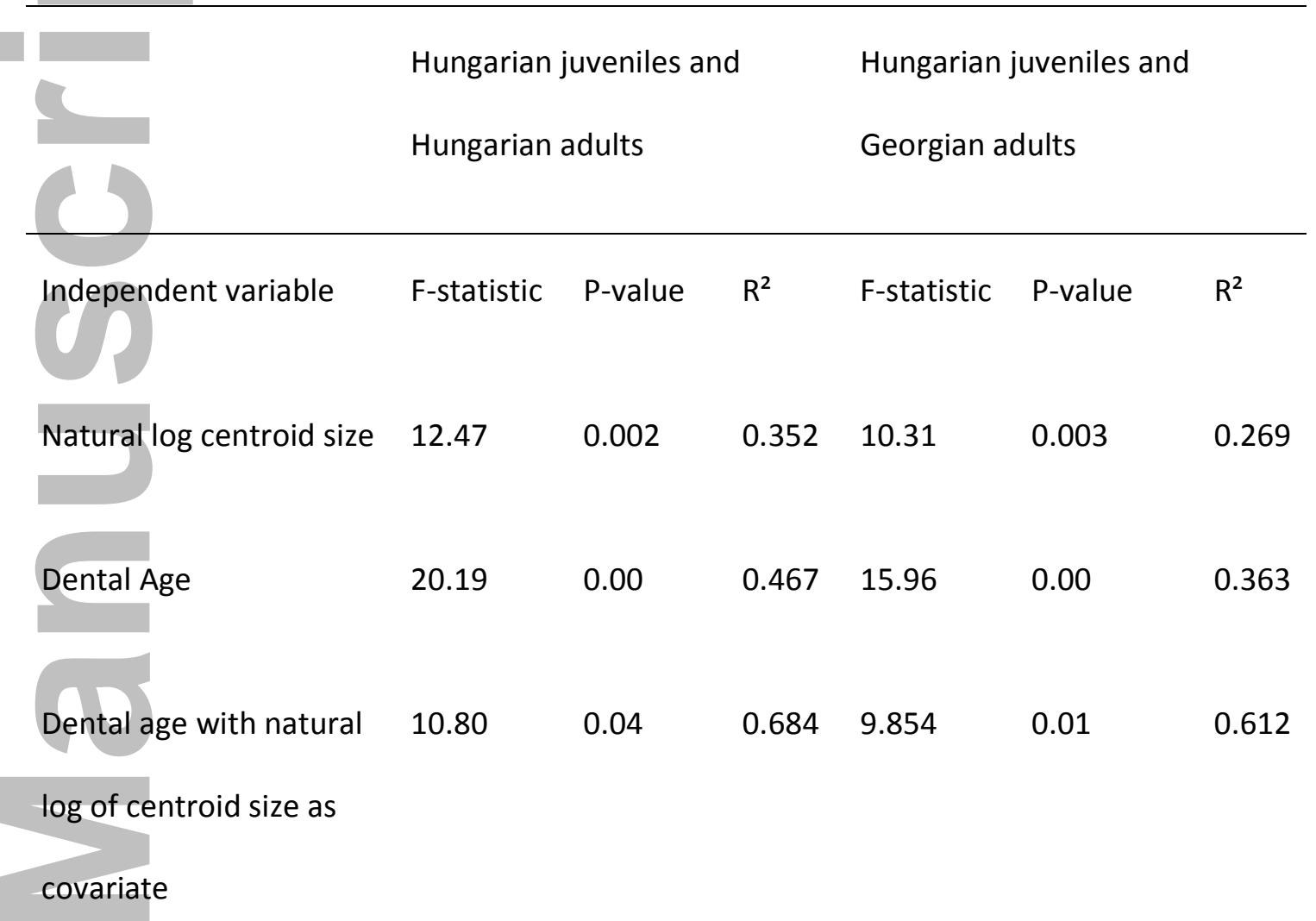

John Wiley \& Sons, Inc.

This article is protected by copyright. All rights reserved. 


\section{Figure legends}

Figure 1. Map of Hungary showing sites with modified crania used in this study

Figure 2. Map of Georgia showing sites of modified crania used in this study

Figure 3. Digitalised cranial surface

Figure 4. Plot of the first and second principal component axes of Georgian adult and Hungarian adult and juvenile modified crania with polygons demarcating groups

Figure 5. Regression of Procrustes Distance by Natural Log of Centroid size. A. Hungarian juveniles and Hungarian adults. B. Hungarian juveniles and Georgian adults

Figure 6. Regression analysis curve: Estimated marginal means of Procrustes distance by dental age

Figure 7. Mean Procrustes distance by Dental Age

Figure 8. Warping of cranial shape on a template cranium along Principal Component One

Figure. 9. Comparison of juvenile and adult modified cranial shape in Hungary shown on example crania

Figure 10. Georgian and Hungarian modified crania showing presumed styles of binding

Figure 11. Superior views showing bilobed cranium in 118855 and impression of pressure pads in 355515 


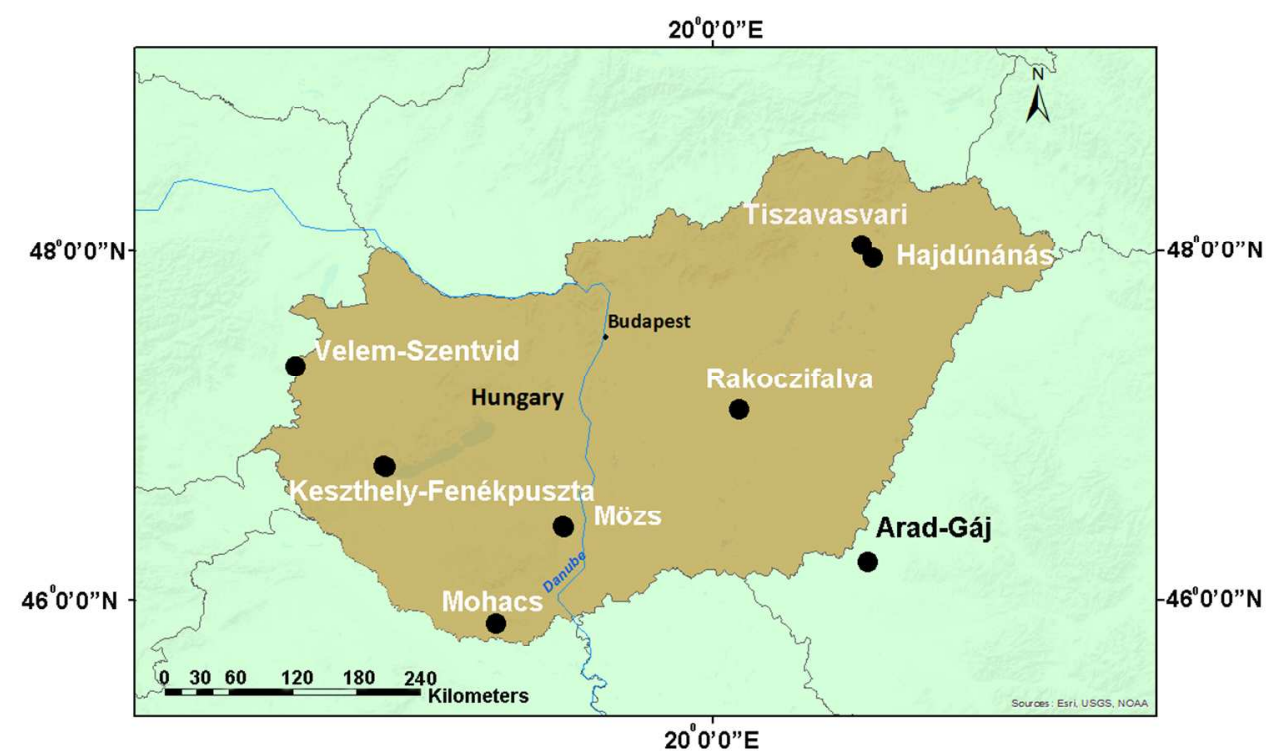

Figure 1. Map of Hungary showing sites with modified crania used in this study $339 \times 210 \mathrm{~mm}(96 \times 96 \mathrm{DPI})$ 


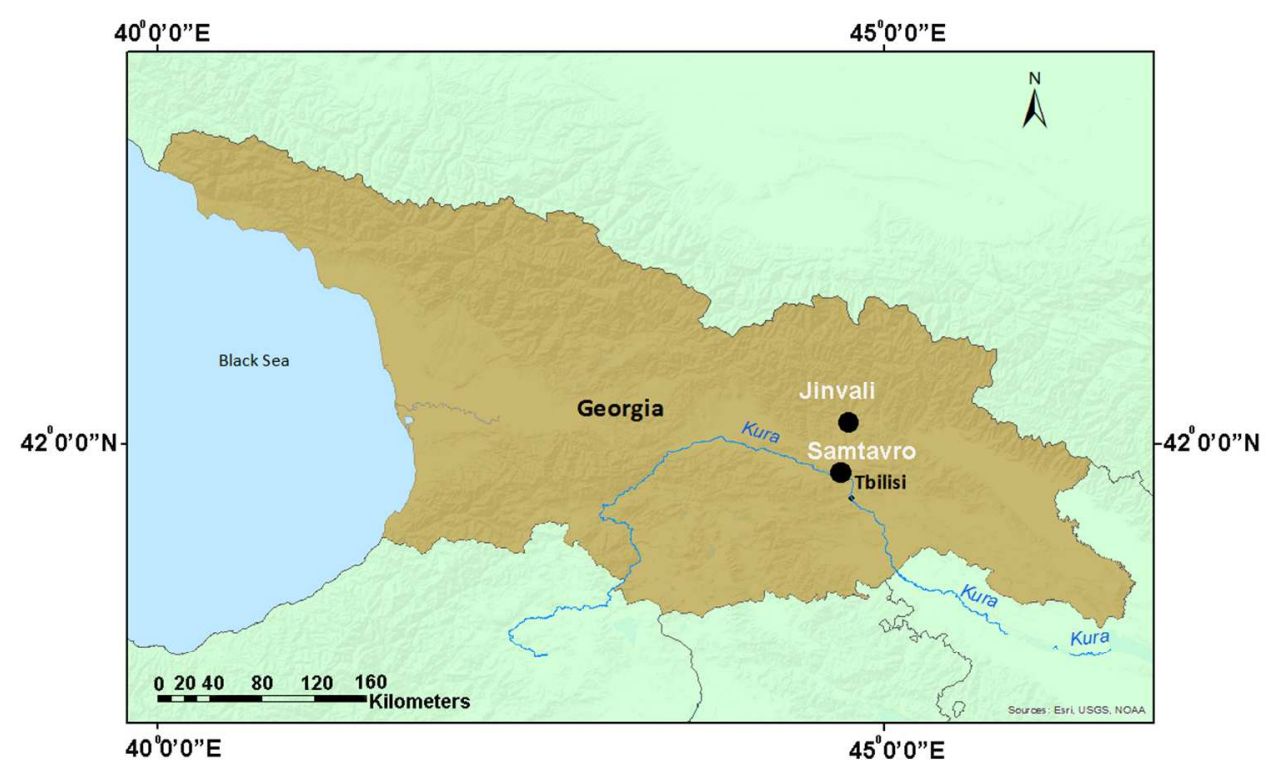

Figure 2. Map of Georgia showing sites of modified crania used in this study $338 \times 210 \mathrm{~mm}(96 \times 96 \mathrm{DPI})$

John Wiley \& Sons, Inc. 


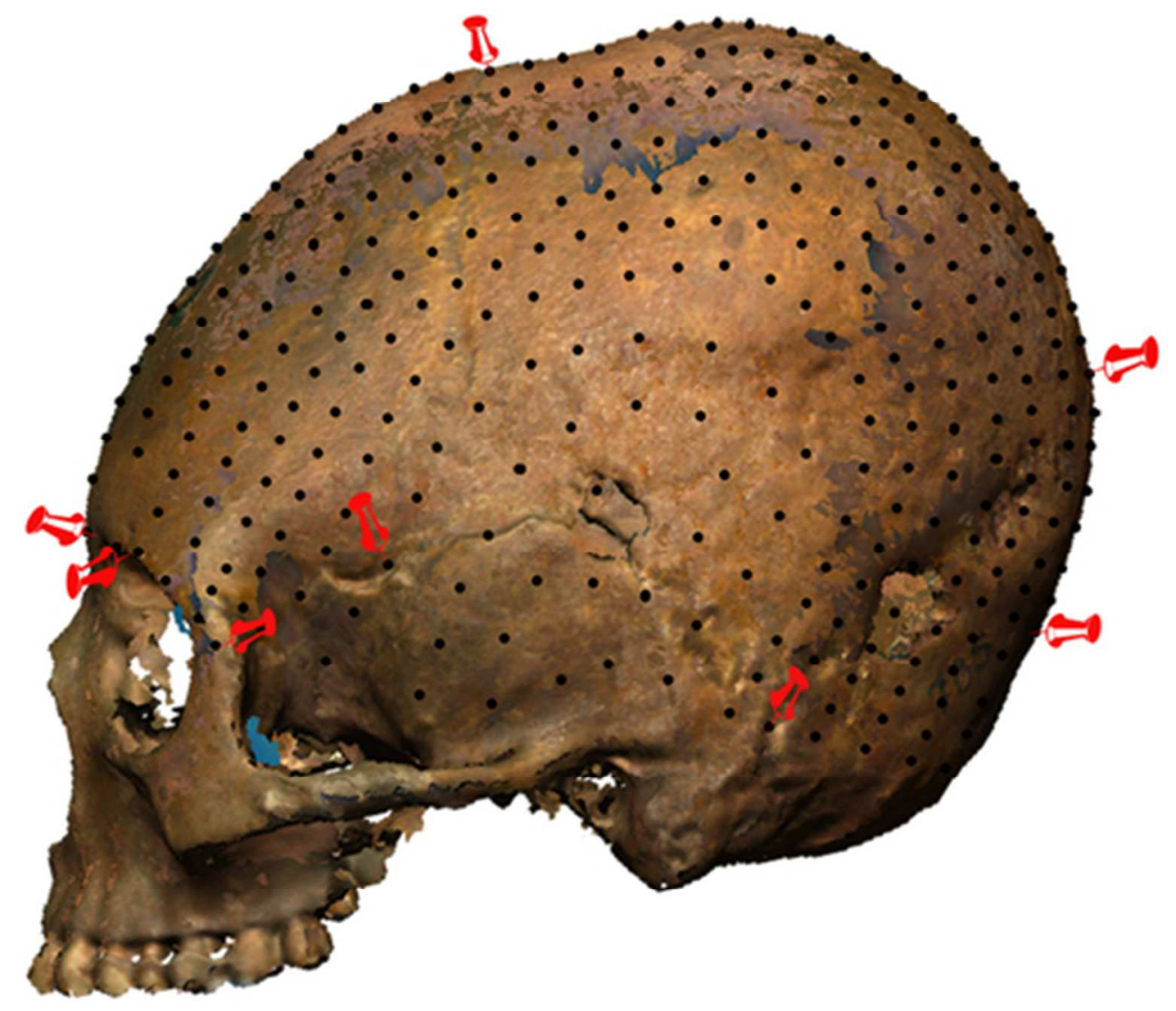

Figure 3. Digitalised cranial surface

$42 \times 36 \mathrm{~mm}(300 \times 300 \mathrm{DPI})$

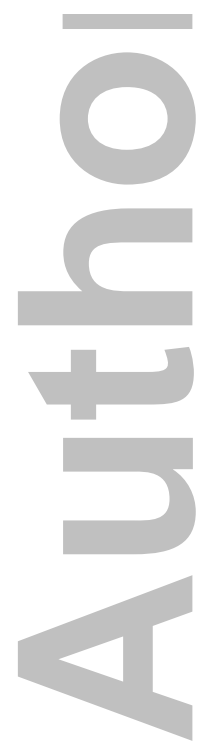

John Wiley \& Sons, Inc.

This article is protected by copyright. All rights reserved. 


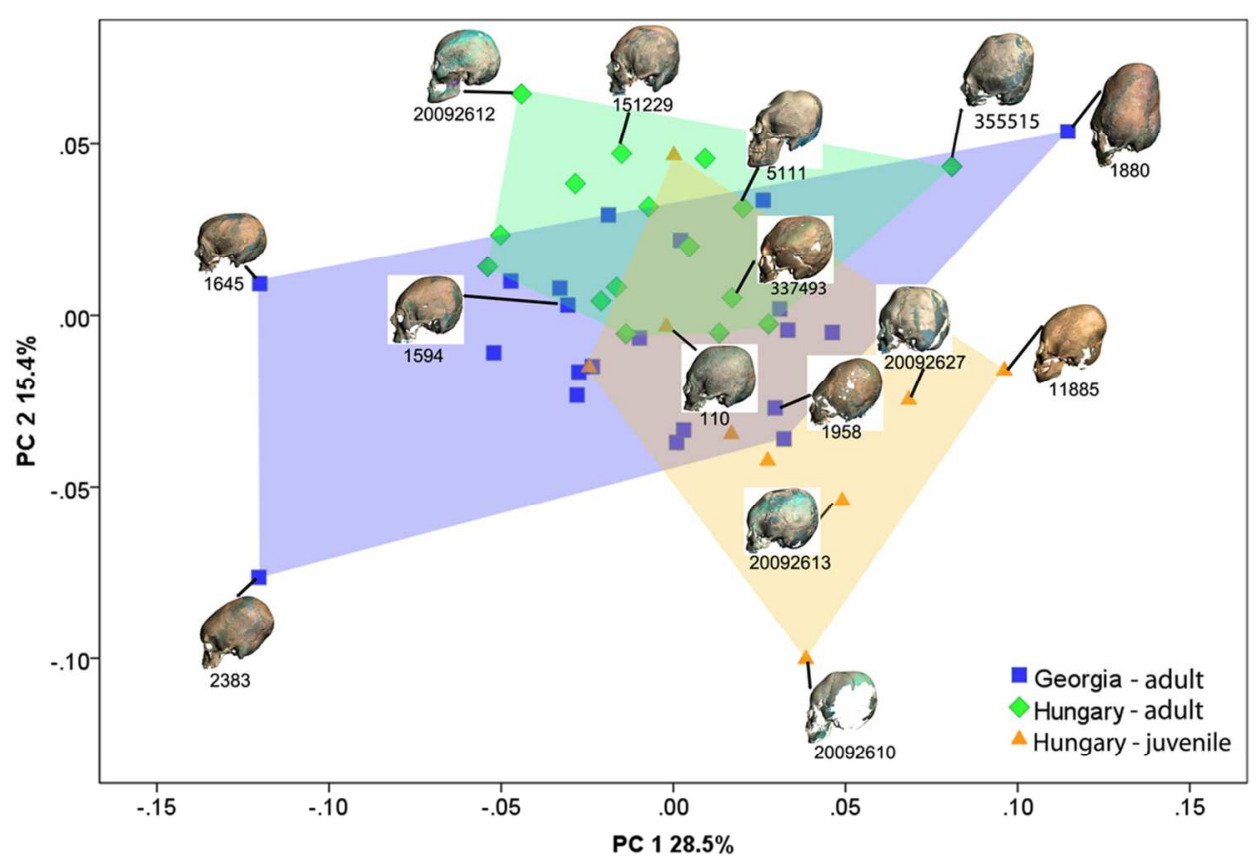

Figure 4. Plot of the first and second principal component axes of Georgian adult and Hungarian adult and juvenile modified crania with polygons demarcating groups

$99 \times 66 \mathrm{~mm}(300 \times 300 \mathrm{DPI})$

John Wiley \& Sons, Inc.

This article is protected by copyright. All rights reserved. 


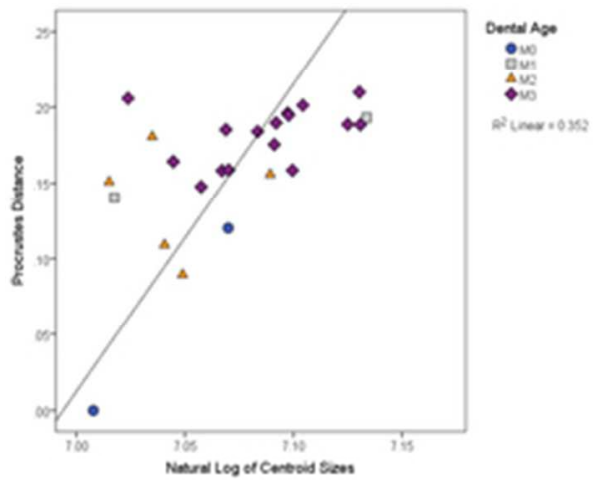

sA

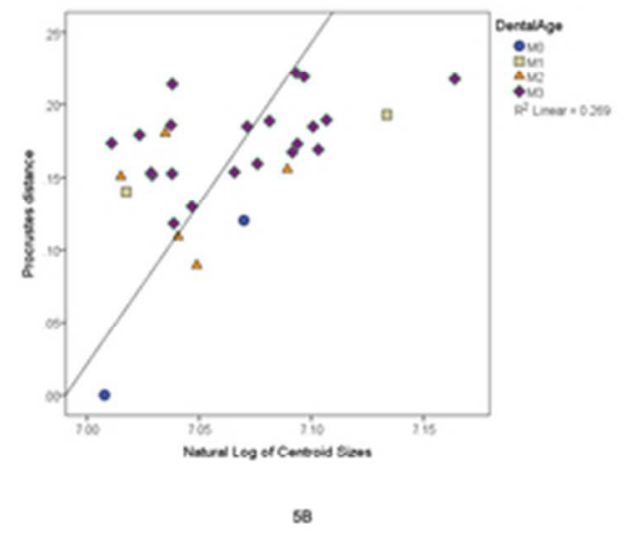

Figure 5. Regression of Procrustes Distance by Natural Log of Centroid size. A. Hungarian juveniles and Hungarian adults. B. Hungarian juveniles and Georgian adults

$42 \times 20 \mathrm{~mm}(300 \times 300 \mathrm{DPI})$

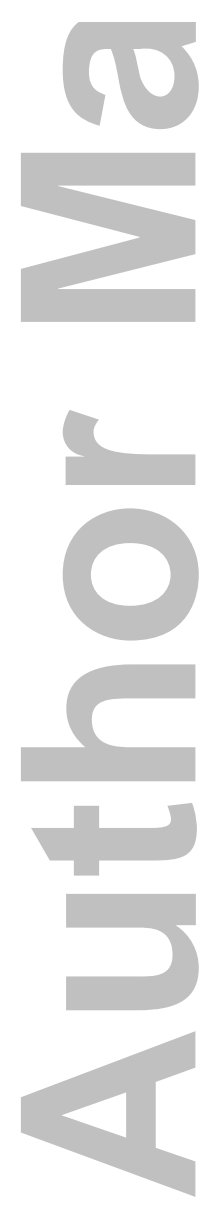

John Wiley \& Sons, Inc.

This article is protected by copyright. All rights reserved. 


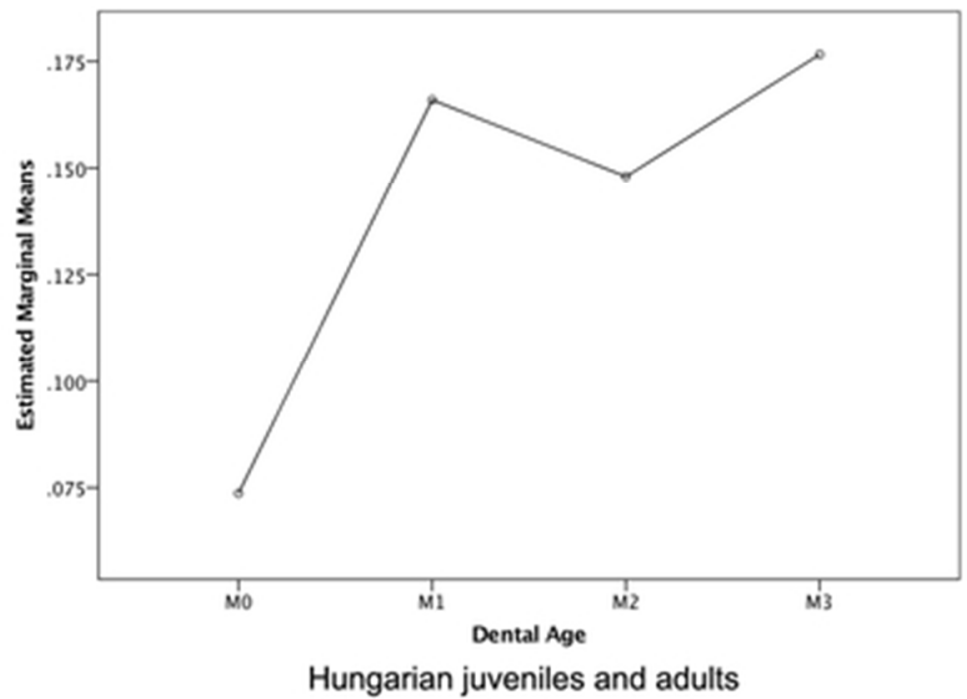

Figure 6. Regression analysis curve: Estimated marginal means of Procrustes distance by dental age $31 \times 23 \mathrm{~mm}(300 \times 300 \mathrm{DPI})$

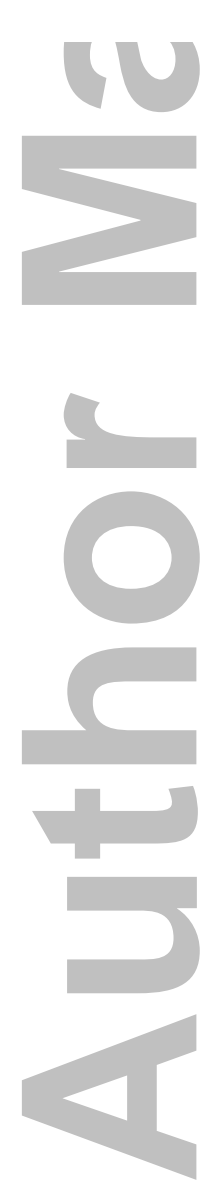

John Wiley \& Sons, Inc. 


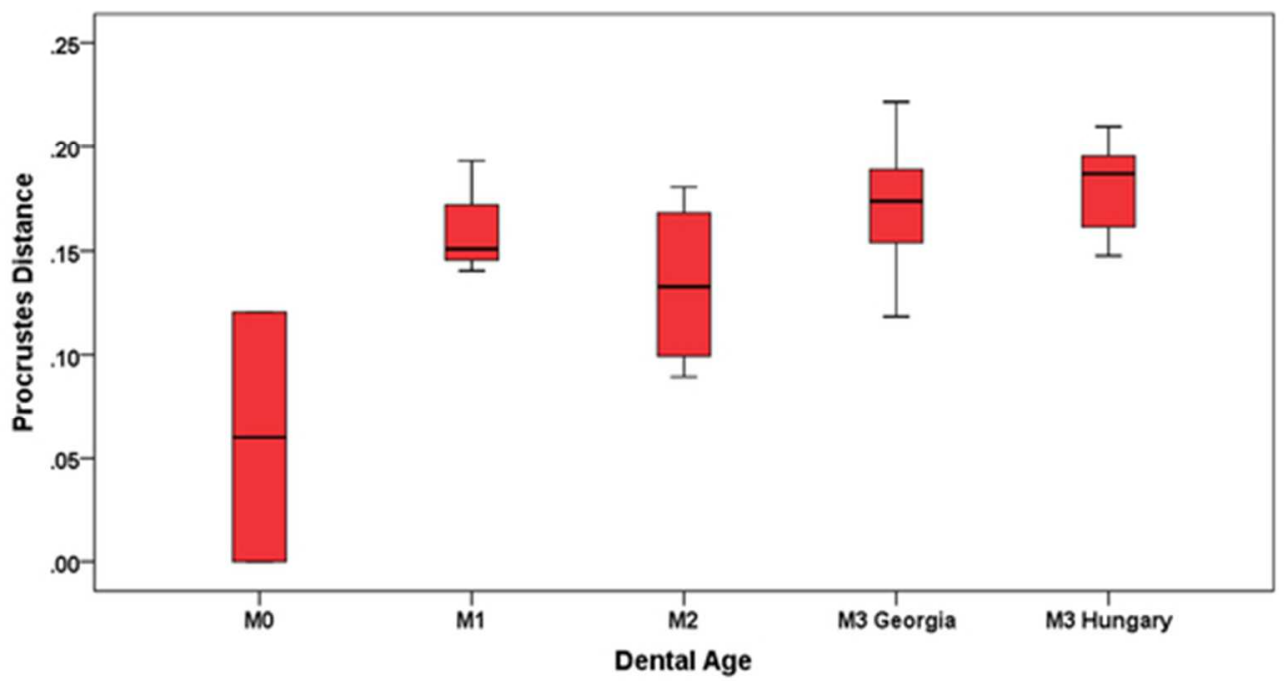

Figure 7. Mean Procrustes distance be Dental Age

$47 \times 24 \mathrm{~mm}(300 \times 300$ DPI $)$

John Wiley \& Sons, Inc.

This article is protected by copyright. All rights reserved. 

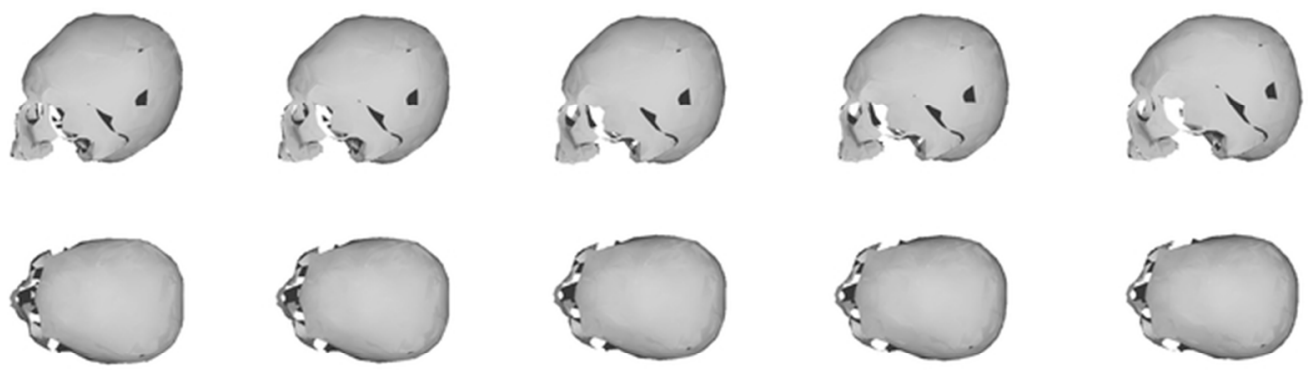

Juvenile

Adult

Figure 8. Warping of cranial shape on a template cranium along Principal Component One $58 \times 22 \mathrm{~mm}(300 \times 300 \mathrm{DPI})$

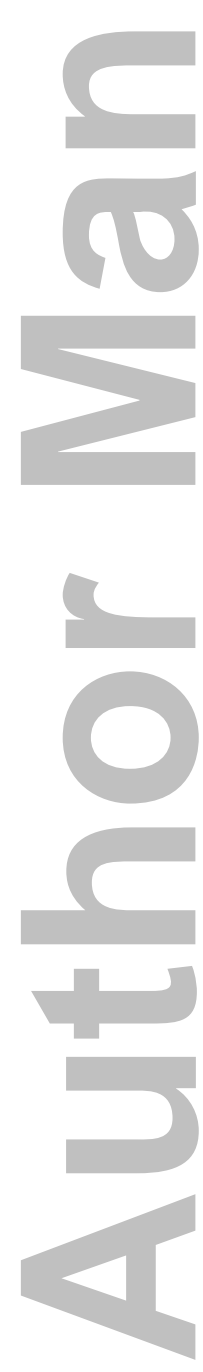

John Wiley \& Sons, Inc. 

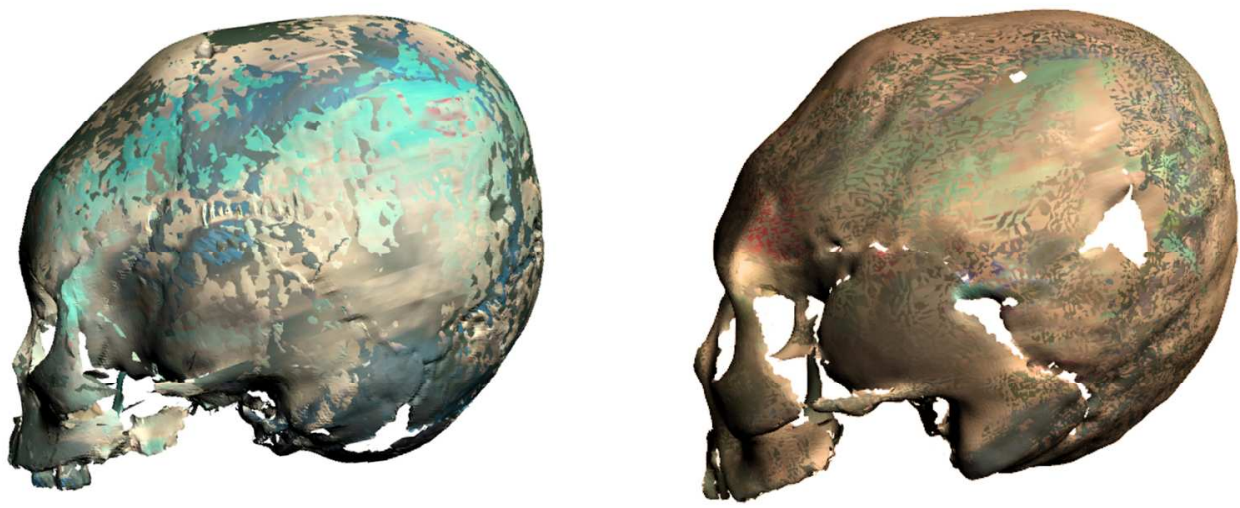

20092613 Keszthely-Fenékpuszta

337493 Hajdúnánás-Furjhalom
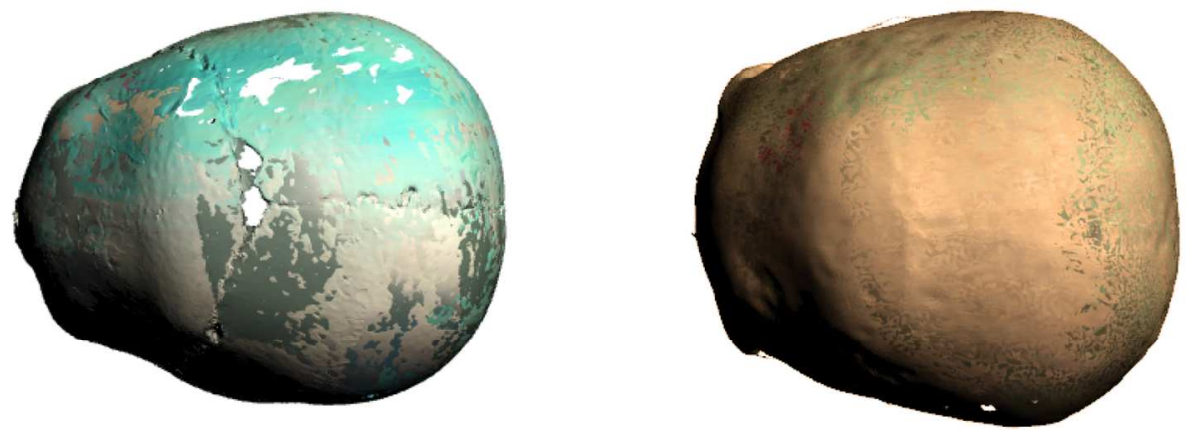

Figure. 9. Comparison of juvenile and adult modified cranial shape in Hungary shown on example crania $132 \times 106 \mathrm{~mm}(300 \times 300 \mathrm{DPI})$

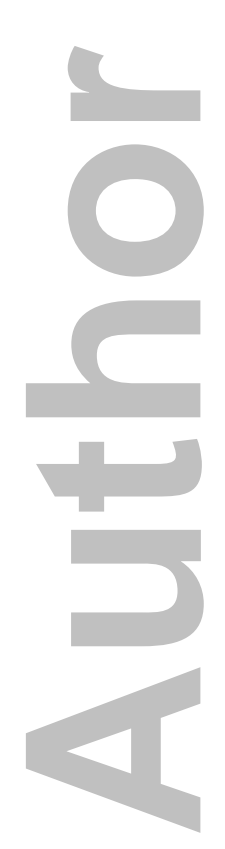

John Wiley \& Sons, Inc.

This article is protected by copyright. All rights reserved. 

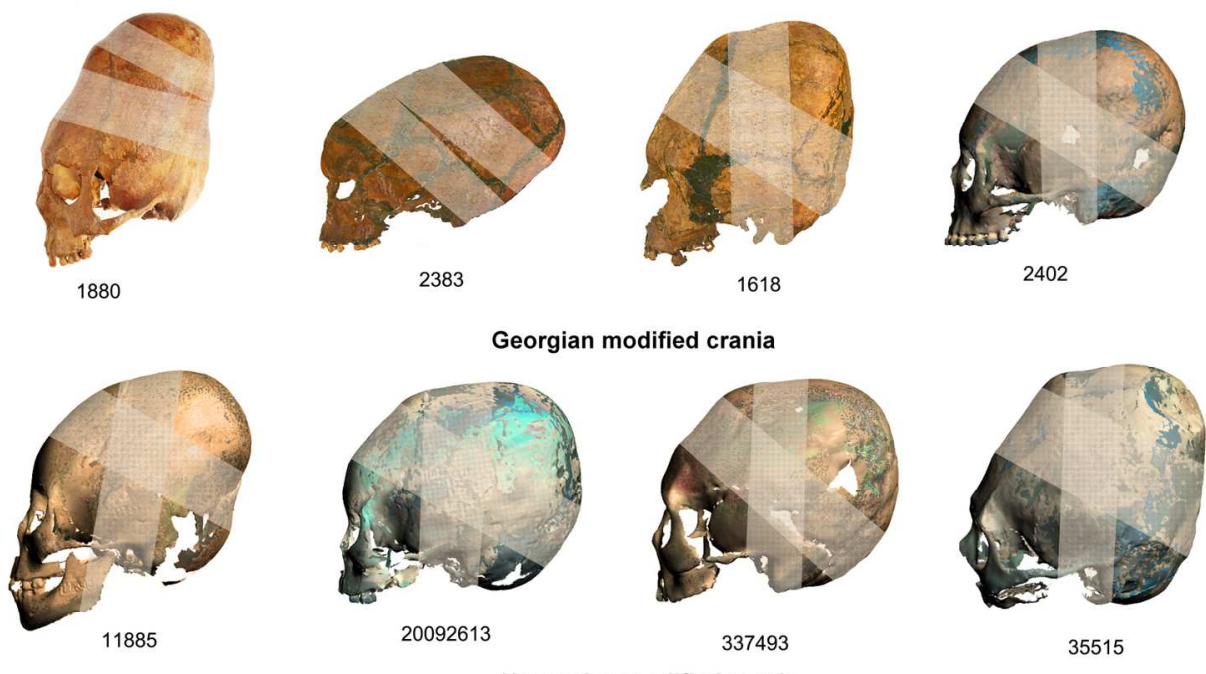

Figure 10. Georgian and Hungarian modified crania showing presumed styles of binding $154 \times 86 \mathrm{~mm}(300 \times 300 \mathrm{DPI})$

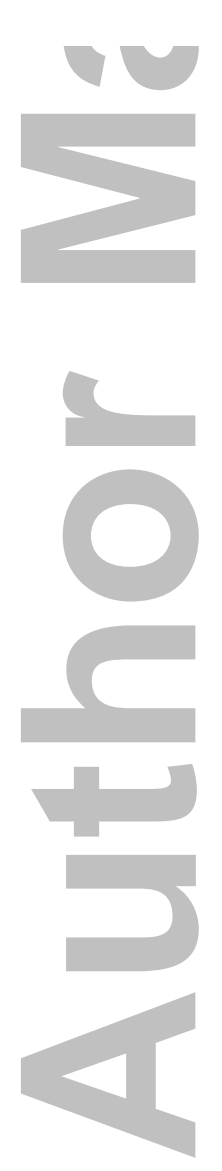

John Wiley \& Sons, Inc. 


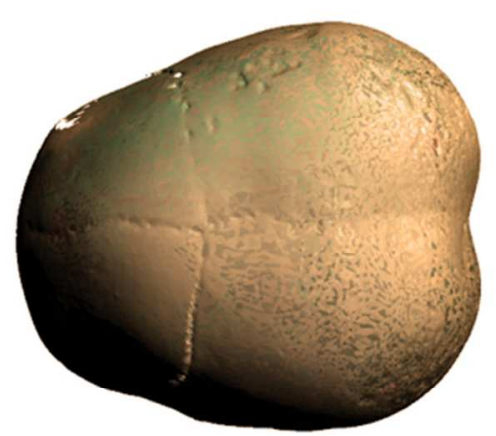

118855 Mözs

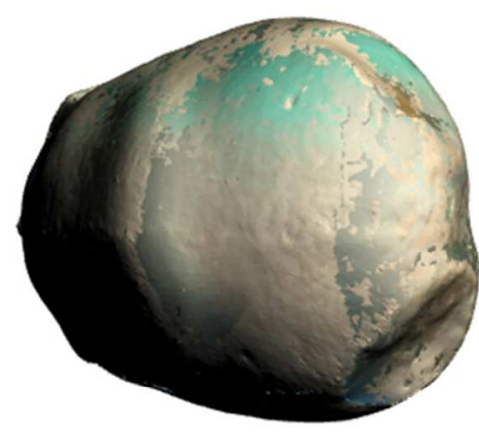

355515 Hajdúnánás-Furjhalom

Figure 11. Superior views showing bilobed cranium in 118855 and impression of pressure pads in 355515 $68 \times 28 \mathrm{~mm}(300 \times 300 \mathrm{DPI})$

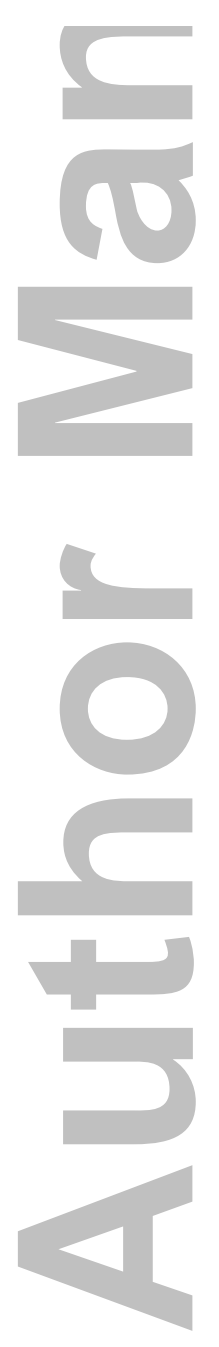

John Wiley \& Sons, Inc.

This article is protected by copyright. All rights reserved. 


\section{University Library}

\section{- M I N E R VA}

\section{A gateway to Melbourne's research publications}

Minerva Access is the Institutional Repository of The University of Melbourne

Author/s:

Mayall, P;Pilbrow, V

Title:

Generalized Procrustes analysis of an ontogenetic series of modified crania: Evaluating the technique of modification in the Migration Period of Europe (4th-7th century AD)

Date:

2018-05-01

\section{Citation:}

Mayall, P. \& Pilbrow, V. (2018). Generalized Procrustes analysis of an ontogenetic series of modified crania: Evaluating the technique of modification in the Migration Period of Europe (4th-7th century AD). AMERICAN JOURNAL OF PHYSICAL ANTHROPOLOGY, 166 (1), pp.156-169. https://doi.org/10.1002/ajpa.23412.

Persistent Link:

http://hdl.handle.net/11343/283573 